\title{
CALCULATED RADIOACTIVITY OF THE FFTF PRIMARY SODIUM SYSTEM DUE TO MASS TRANSFER
}

G.P. WOZADLO C.E. BOARDMAN M.L. WEISS 


\section{DISCLAIMER}

This report was prepared as an account of work sponsored by an agency of the United States Government. Neither the United States Government nor any agency Thereof, nor any of their employees, makes any warranty, express or implied, or assumes any legal liability or responsibility for the accuracy, completeness, or usefulness of any information, apparatus, product, or process disclosed, or represents that its use would not infringe privately owned rights. Reference herein to any specific commercial product, process, or service by trade name, trademark, manufacturer, or otherwise does not necessarily constitute or imply its endorsement, recommendation, or favoring by the United States Government or any agency thereof. The views and opinions of authors expressed herein do not necessarily state or reflect those of the United States Government or any agency thereof. 


\section{DISCLAIMER}

Portions of this document may be illegible in electronic image products. Images are produced from the best available original document. 


\section{CALCULATED RADIOACTIVITY OF THE \\ FFTF PRIMARY SODIUM SYSTEM DUE TO MASS TRANSFER}

G. P. Wozadlo

C. E. Boardman

M. L. Weiss
Approved:

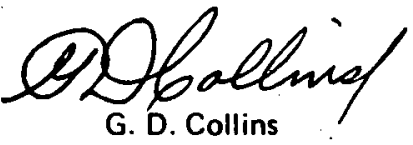

Project Engineer
Approved: $\quad$ 2.0.3efosse:

E. L. Zebroski, Manager

Development Engineering

Prepared for the

U. S. Atomic Energy Commission

Under Contract Number AT(04-3)-189

Project Agreement 15

NOTICE

This report was prepared as an account of work sponsored by the United States Government. Neither the United States nor the United States Atomic Energy Commission, nor any of their employees, nor any of thelr cunlrucluss, subcintrnetora, or thoir employees, makes any warranty, express or implied, or assumes any legal liability or responsibility for the accuracy, completeness or usefulness of any information, apparatus, product or process disclosed, or represents that its use would not infringe privately owned rights.

BREEDER REACTOR DEPARTMENT — GENERAL ELECTRIC COMPANY SUNNYVALE, CALIFORNIA 94086

\section{GENERAL (GLCTRIC}




\section{NOTICE}

This report was prepared as an account of work sponsored by the United States Government. Neither the United States nor the United States Atomic Energy Commission, nor any of their employees, nor any of their contractors, subcontractors, or their employees, makes any warranty, express or implied, or assumes any legal liability or responsibility for the accuracy, completeness or usefulness of any infor. mation, apparatus, product or process disclosed, or represents that its use would not infringe privately owned rights. 


\section{TABLE OF CONTENTS}

Page

1.

SUMMARY

2. INTRODUCTION . . . . . . . . . . . . . . . . . . . . . . . . . . . 2-1

2.1 Background . . . . . . . . . . . . . . . . . . . . . . . . . . . . 2-1

2.2 Objectives . . . . . . . . . . . . . . . . . . . . . . . . . . . . . 21

2.3 General Approach . . . . . . . . . . . . . . . . . . . . . . . . . 2-1

3. MASS TRANSFER AND DEPOSITION IN FLOWING SODIUM SYSTEMS . . . . . . . . . . . . 3-1

3.1 Observations . . . . . . . . . . . . . . . . . . . . . . . . . . . . $3-1$

3.2 Corrosion-Deposition Data, Use and Limitations . . . . . . . . . . . . . . . . . . 3-1

3.2.1 Limitations . . . . . . . . . . . . . . . . . . . . . . . . . . 36

3.3 Radioactive Mass Transport Data $\quad . \quad$. . . . . . . . . . . . . . . . . . . . . . . . . . . . $3-7$

3.3.1 Radioisotope Transport and Deposition in Flowing Sodium, BNWL . . . . . . . . . $3-7$

3.3.2 Source Term Computer Program (STP-1), Al . . . . . . . . . . . . . . 3.7

4. ACTIVITY ESTIMATES . . . . . . . . . . . . . . . . . . . . . . . 4-1

4.1 FFTF Operating Parameters and Design . . . . . . . . . . . . . . . . . . . . . . . 4-1

4.2 Extrapolation of P.A. 15 Mass Transfer Data to FFTF Operation Conditions . . . . . . . . 4-1

4.3 Calculation of the Mass Transfer of the FFTF . . . . . . . . . . . . . . . . . 4-1

4.3.1 Mass Transfer Rates . . . . . . . . . . . . . . . . . . . . . . . 4-1

4.3.2 End-of-Life Mass Transfer . . . . . . . . . . . . . . . . . . . . . . . . 4.1

4.3.3 End-of-Life Weight Changes . . . . . . . . . . . . . . . . . . . . 4-1

4.3.4 Weight of Nickel (Cobalt) and Manganese . . . . . . . . . . . . . . . . 4-1

4.4 Calculation of the Activity of Cobalt-58, Cobalt-60, and Manganese-54 .

4.5 Calculation of the Dose Rate at the "Key" Components . . . . . . . . . . . . . . . . . . . 48

5. RECOMMENDED RESEARCH . . . . . . . . . . . . . . . . . . . . . 5.1

REFERENCES . . . . . . . . . . . . . . . . . . . . . . . . . R-1

\section{APPENDICES}

A. CALCULATION OF FFTF FUEL PIN CORROSION RATES . $\quad . \quad . \quad . \quad . \quad . \quad . \quad . \quad . \quad . \quad . \quad . \quad . \quad . \quad$ A-1

B. SUMMARY OF MEETING WITH WADCO . . . . . . . . . . . . . . . . . . . . . B-1

DISTRIBUTION . . . . . . . . . . . . . . . . . . . . . . . . 


\section{LIST OF ILLUSTRATIONS}

Figure

Title

Corrosion Rate of Type-316 Stainless Steel versus Sodium Temperature ～. . . . . . . . . 3-2

Deposition Rate versus Temperature, 3 gpm Flow Rate (2 Runs) . . . . . . . . . . . . 3-3

Deposition Rate versus Temperature, 6 gpm Flow Rate (3 Runs) . . . . . . . . . . . . 33

Concentration versus Temperature, 3 and $6 \mathrm{gpm}$ Flow Rates (7 Runs) . . . . . . . . . . . 3-5

Effect of Mass Flow Rate on the Temperature Gradients in Loops 8 and 9 . . . . . . . . . . . $3-5$

Schematic of an FFTF Loop Showing the Operating Parameters Assumed . . . . . . . . . . . 4-4

Deposition Rate versus Temperature for FFTF System Conditions . . . . . . . . . . . . . . 4-5

Deposit Composition versus Temperature for FFTF System Conditions . . . . . . . . . . . 4.5

Buildup of Radioactivity in the FFTF Primary System with Uniform Deposition and

0.10 wt \% Cobalt in the Core Materials

Effect of Increasing Hot Channel Coolant Exit Temperature on the Corrosion Rate of

Type-316 Stainless Steel . . . . . . . . . . . . . . . . . . . . . . . . 4-11

Graphical Calculation of Average Fuel Pin Corrosion Rate . . . . . . . . . . . . . . A-1

\section{LIST OF TABLES}

Table
Title

Recommended Source Rates for Type-316 Stainless Steel

FFTF Core and Primary Sodium System Design Data Used

FFTF Fuel Design

Summary of FFTF Primary System Data (All Loops) .

Summary of FFTF Primary System Mass Transfer (All Loops) . . . . . . . . . . . . . . . . . . . 4.4

Volume-Averaged Flux and Cross Sections

Results of Distributing Total Mass (Pounds in 20 Years) Between Four Regions of the FFTF . . . 4-7 Radio-Corrosion Product Activity Released to the FFTF Primary Coolant System (20 Years) . . 4-7

Percentage in Component of Total Cobalt and Manganese Deposit c . . . . . . . . . . . . . . 4-8

Radio-Corrosion Product Activity Deposited in One Loop of the FFTF Primary

Coolant System (20 Years)

Nomalized Radiation Intensity at 2 feet from the Surface $(R / h)$.

Dose Rates (After 20 Years) of the Key Components in One Loop of the FFTF at 2 feet from the Surface $(R / h)$. 


\section{SUMMARY}

The radioactivity deposited in the cooling system of an FFTF by corrosion and mass transport has been reestimated on a basis which includes the exchange of data and analytical methods between GE and WADCO. The calculated intensity levels predicted would not permit contact maintenance of key components after 20 years, and only very limited access during the initial year of operation.

The most important isotopes are cobalt-60, manganese-54, and cobalt-58. The estimated range of dose rates at a distance of 2 feet from key components after 20 years of FFTF operation is:

$\begin{array}{lc}\text { IHX } & 5.5-130 \mathrm{R} / \mathrm{h}^{*} \\ \text { Cold-leg piping } & 50-90 \mathrm{R} / \mathrm{h} \\ \text { Cold trap } & 0-45 \mathrm{R} / \mathrm{h}^{* *} \\ \text { Hot-leg piping } & <0.5 \mathrm{R} / \mathrm{h} \\ \text { Primary pump } & <0.5 \mathrm{R} / \mathrm{h}\end{array}$

The results are based on current state-of-the-art values and analyses; considerable uncertainty in the calculated results exists. The values stated are believed to be conservative, rather than optimistic.

The major assumptions or bases for these results are:

- The constituent elements of stainless steel are released in accordance with the alloy composition."**

- Deposition rate is proportiunal to corrosion rate.

- Deposition rate is proportional to sodium velocity.

- Deposition rate is proportional to the temperature gradient along the cold leg.

- Cobalt transport follows nickel.

- Deposits build up continuously and do not spall or erode.

- Cold trap efficiency is high.

Tests in progress under the Sodium Mass Transfer Program will confirm or modify all of these assumptions. Additional work is identified for definitive determination of the effects of boundary layer thickness which is needed for rational scale-up to large-size ducts or piping, and to determine more accurately the effect of limiting temperature (and temperature gradients) in extending the time in which adequate access for surveillance and maintenance would be possible.

\footnotetext{
- The smaller dose rate of $5.5 \mathrm{R} / \mathrm{h}$ is for the $\mathrm{IHX}$ with tube bundles remaining inside the shell and $80 \%$ full of sodium. The larger dose rate is with the tube bundles out of the shell, drained, and where no deposition occurs in the cold trap.

" The dose rate of $\mathrm{O} \mathrm{R} / \mathrm{h}$ is for the case where no deposition occurs in the cold trap.

*** Neglecting an initial transient during which a compositionally altered surface layer is established.
} 


\section{INTRODUCTION}

\subsection{BACKGROUND}

The anticipated operating conditions for the FFTF will pose radioactivity problems unique in fast reactor experience. The combination of high operating temperatures and neutron fluxes, coupled with long burnups, is expected to produce radioactive corrosion products at a rate approximately 100 times higher than any encountered in past experience.

\subsection{OBJECTIVES}

The study reported here was intended to apply the "best available" state-of-the-art to:

a. Estimate the rate and level of radioactive contamination of key components of a primary FFTF system as a result of the deposition of activated corrosion products.

b. Define the factors controlling the deposition.

c. Evaluate the uncertainty of the overall analysis and contributing parameters.

d. Provide guidance for more definitive tests of the transport of radioactive material.

\subsection{GENERAL APPROACH}

The general approach used in this study to calculate the expected contamination levels in the FFTF primary loops is given as follows:

a. Compile the controlling operating parameters (i.e., temperatures, velocities, and surface areas) of FFTF.

b. Compile and correlate the applicable corrosion and deposition data for the FFTF operation conditions.

c. Calculate the mass losses and gains (corrosion and deposition) for each region.

d. Calculate the activity of cobalt-58, cobalt -60 , and manganese-54 released due to corrosion and deposited in the key components.

e. Calculate the dose rate in the vicinity of the key components. 


\section{MASS TRANSFER AND DEPOSITION IN FLOWING SODIUM SYSTEMS}

\subsection{OBSERVATIONS}

Data from Loops 8, 9, and $1 R$ in the P.A. 15 program provide semi-quantitative distributions for the main alloy elements as a function of a $1300^{\circ} \mathrm{F}$ peak system temperature and an oxygen content of about $4 \mathrm{ppm}$. The principal parameters governing deposition are:

- The source rate (corrosion rate), which is a function of temperature, oxygen, and velocity. Corrosion of the elements of an alloy are presumed to be stoichiometric at or near the peak temperature of $1300^{\circ} \mathrm{F} .{ }^{*}$

- The temperature profile along the loop, in the cold leg.

- The Reynolds number $\left(N_{R}\right)$ in the cold leg, including the degree of local turbulence, and the boundary layer velocity profile.

The observations made to date indicate that the rate of cooling influences the following:

- The chemical nature of the deposits (compounds present).

- The morphology of the deposits (size and shape of the particles).

- The strength of the mechanical or diffusion bond between the deposits and the substrate material.

$N_{R}$, describing turbulence, influences the quantity of material deposited locally lultimate thickness of the deposit), the ratio of alloy elements, and the morphology of the deposit. These factors also influence the amount and type of radioactivity in the primary system.

\subsection{CORROSION-DEPOSITION DATA, USE AND LIMITATIONS (P. A. 15 and Thorley, et al.). ${ }^{1}$}

The available mass transfer data from P. A. 15 and the UK provide a basis from which total weight loss rates in sodium systems of interest to reactor design can be calculated (source term). The presently recommended source rates for Type-316 stainless steel are shown in Table 3-1 and Figure 3-1 for sodium velocities of 15 to $28 \mathrm{ft} / \mathrm{sec}$ and an oxygen content of approximately $4 \mathrm{ppm}$. The main area of uncertainty surrounding the corrosion rates is the effect of oxygen content of the sodium.

\section{Table 3-1 \\ RECOMMENDED SOURCE RATES FOR TYPE-316 STAINLESS STEEL}

$\begin{array}{cc}\begin{array}{c}\text { Temperature } \\ \text { ('F) }\end{array} & \begin{array}{c}\text { Corrosion Rate } \\ \text { (mils/year) }\end{array} \\ 1300 & 1.15 \\ 1200 & 0.65 \\ 1100 & 0.33 \\ 1000 & 0.17 \\ 900 & 0.07\end{array}$

The P.A. 15 program is the only published source of systematic deposition data available at the present time. All of the data have been obtained in mass transfer loops operating at a maximum temperature of $1300^{\circ} \mathrm{F}$ and an oxygen content of $2.5 \pm 1.5 \mathrm{ppm}$. Two flow rates, 3 and $6 \mathrm{gpm}$, were studied. The sodium velocities were directly dependent on the flow rates, since the piping and sample configuration were maintained constant. The deposition patterns for the two flow rates are shown in Figures 3-2 and 3-3.

Three items of specific interest should be noted from the two figures:

a. The peak deposition rate at $3 \mathrm{gpm}$ is about half that for $\mathbf{6 g p m}$ (velocities from about 2 to $\mathbf{4 f t} / \mathrm{sec}$ ).

b. The peak deposition rate occurs at a higher temperature for the lower flow rate.

c. A second deposition peak occurs at $\sim 800^{\circ} \mathrm{F}$ in the 3-gpm tests.

The first item, together with the observation that the corrosion rates were also in the same ratio, provides a good indication that a mass balance was maintained. The reasons for the similarity in these tests are the direct ratio dependency of the sodium velocities to the flow rates, and the hot-leg velocities being in the range $(<15 \mathrm{ft} / \mathrm{sec})$ where the corrosion rates show a linear response to velocity.

- At lower temperatures $\left(<1200^{\circ} \mathrm{F}\right.$ ), the initial transient during which selective, nonstoichiometric corrosion occurs, becomes increasingly important. 


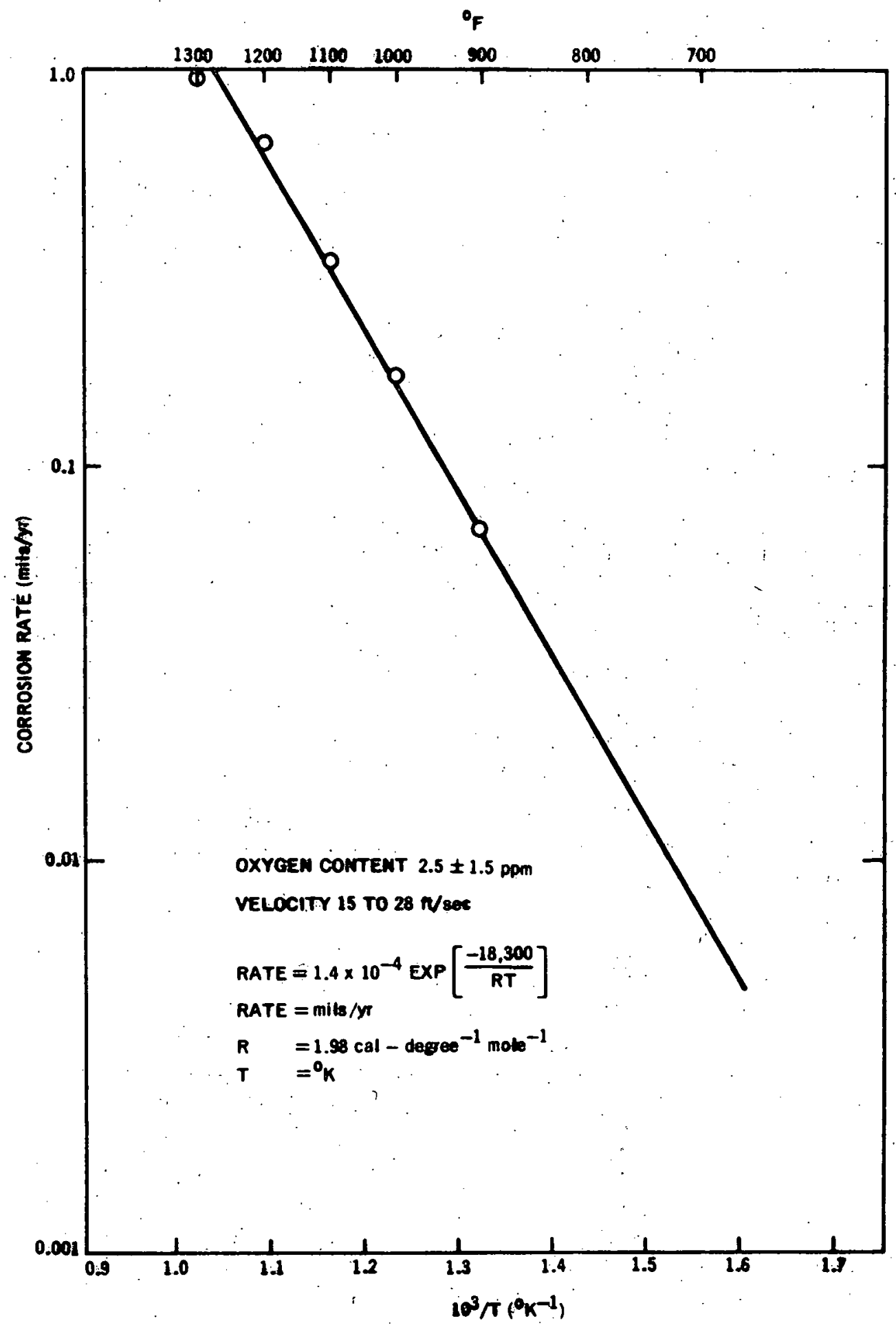

Figure 3-1. Corrosion Rate of Type-316 Stainless Steel versus Sodium Temperature 


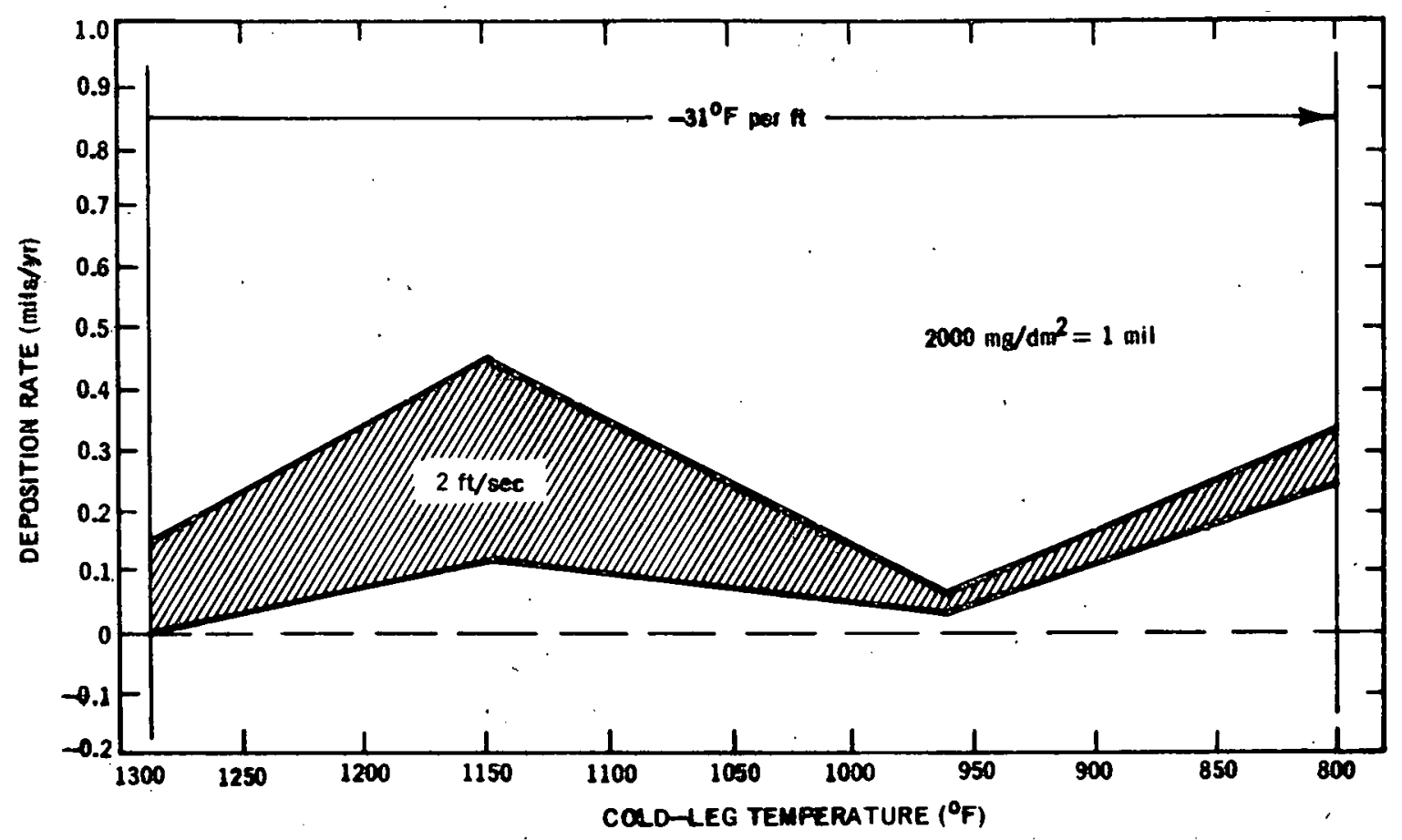

Figure 3-2. Deposition Rate versus Temperature, 3 gpm Flow Rate (2 Runs)

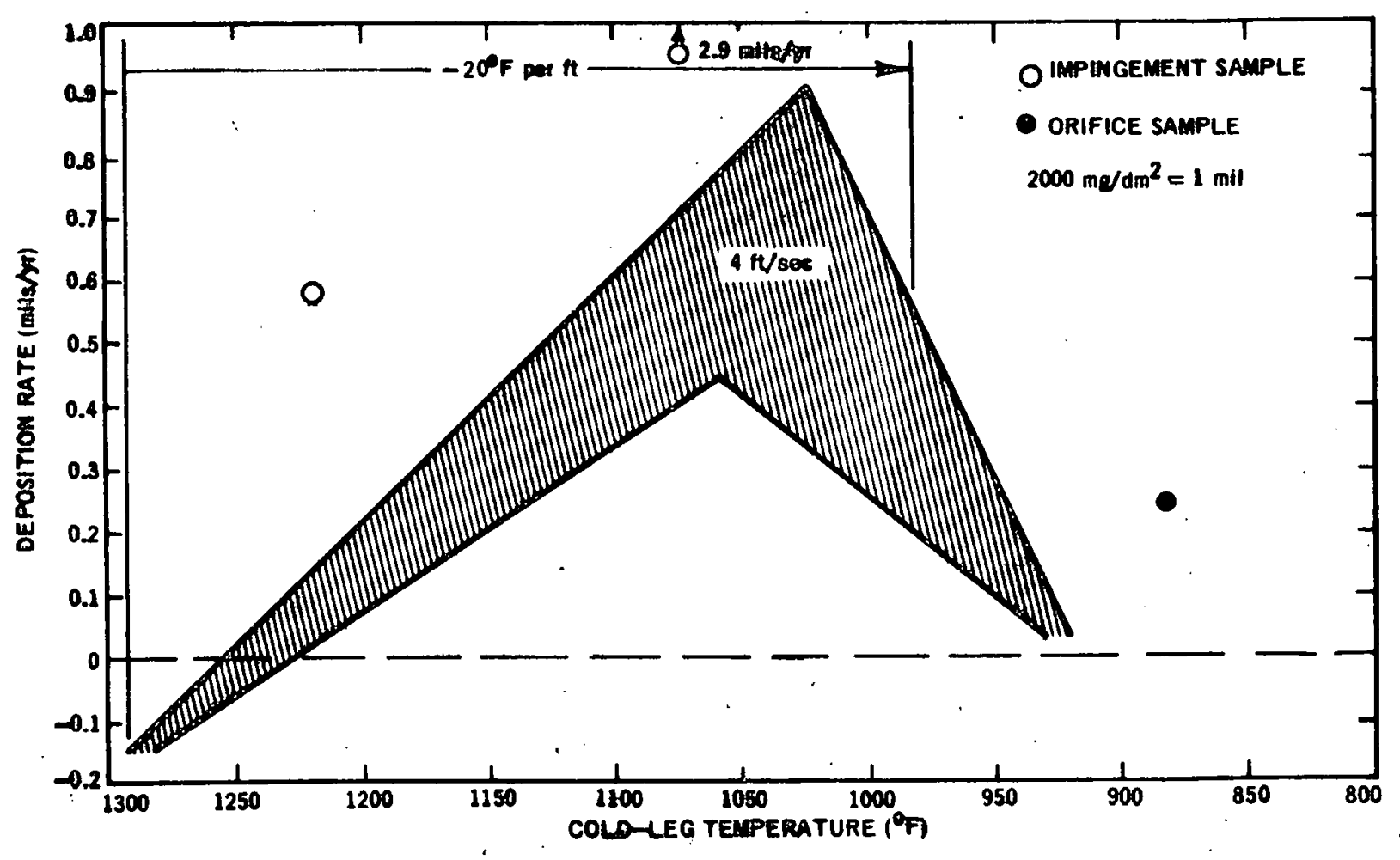

Figure 3-3. Deposition Rate versus Temperature, 6 gpm Flow Rate (3 Runs) 
The second item is predictable upon further analysis. It has been observed ${ }^{2}$ that the deposition of the alloying elements in the hot leg largely depends on the alloy compositions of the substrate. For example, it was found ${ }^{2}$ that pure iron samples placed in the hot leg picked up a considerable amount of chromium and nickel, although the adjacent stainless steel samples lost both of these metals. This observation indicates that the predominant mechanism of deposition in the hot leg involves atomic exchange. The driving force for this process is believed to be the activity gradient of the solutes between the substrate and liquid sodium. The deposition of materials in the cold leg is not significantly affected by the composition of the substrate, ${ }^{2}$ which implies that the process of the atomic exchange is not the predominant mechanism of deposition in the cold leg. A second mechanism of deposition for carbides and chromites has been postulated and generally verified ${ }^{2}$ in which the nucleation of these particulate compounds occurs in the bulk sodium prior to deposition. The implication is that most particulates nucleated in the bulk sodium have to reach a critical size before they can be separated from the sodium. Because deposition is concerned in part with particulate nucleation, deposition-under a linear temperature decrease-manifests itself by increasing to a peak rather than a constant thickness deposit. Since chromium and nickel deposit heavily in the temperature regions of peak deposition (Figure 3-4), and because the solubilities in sodium of chromium and nickel decrease exponentially with decreasing temperature, it follows that a peak in deposition rate is reached beyond which the rate will decrease. A steeper temperature gradient (Figure 3-5) will result in a greater rejection rate of material from the sodium. Based on the foregoing discussion, the particulates will reach their critical size sooner with the steeper temperature gradient. Therefore, the deposition peak will be at a higher temperature in the lower flow rate-steeper temperature gradient situation.

The deposition peak at $800^{\circ} \mathrm{F}$ in the 3-gpm tests is a manifestation of the cooling capacity of the test loops. At a flow rate of $3 \mathrm{gpm}$, the desired minimum temperature of $800^{\circ} \mathrm{F}$ (loop $\left.\Delta \mathrm{T}=500^{\circ} \mathrm{F}\right)$ was achieved. At a flow rate of 6 gpm, the test loops could only achieve a minimum temperature of $\sim 900^{\circ} \mathrm{F}$. Therefore, the second deposition peak, which occurred at $\sim 800^{\circ} \mathrm{F}$ with a flow rate of $3 \mathrm{gpm}$, was not seen at $6 \mathrm{gpm}$. However, it is felt that this second peak at $3 \mathrm{gpm}$ is valid and consists of an iron compound, probably an oxide, which will be discussed later.

The: obvious question now becomes how to use the available deposition data to predict the performance in large systems and at. lower operating temperatures. The first concern is to remove the problem of deposition data obtained at flow rates of 3 and $6 \mathrm{gpm}$ that need to be extrapolated to thousands of gpm. Experiments conducted in the P.A. 15 program indicate that mass flow rate does not have an effect on corrosion rate but that velocity, and particularly Reynolds number, are important. Since the corrosion rate data in Table 3-1 are representative of the primary system velocity parameters (15 to $25 \mathrm{ft} / \mathrm{sec}$ ), the use of the deposition rates in Figures 3-2 and 3-3 becomes a matter of temperature and velocity extrapolation.

Corrosion rate is an exponential function of absolute temperature. ${ }^{3}$ Therefore, the deposition rates in Figures 3-2 and 3.3 will be reduced, using the ratio of corrosion rates versus maximum system temperature shown in Table 3-1 and Figure 3-1.

The temperature of peak deposition from Figures 3-2 and 3-3, which is a function of cooling rate, should be extrapolated directly as a function of the maximum system temperature.

Since the peak deposition temperature is dependent on the temperature gradient ${ }^{*}$ of the reactor system, the temperature gradient must be known or estimated.

Other data ${ }^{2}$ show that deposition rate is directly proportional to velocity up to 15 to $20 \mathrm{ft} / \mathrm{sec}$. Therefore, the deposition rates in Figures 3.2 and 3-3 can be changed, using a direct ratio of velocities to deposition rates. There are two features of the data shown in Figure 3-3 that require clarification: (1) sodium flow impingement, and (2) sodium flow through an orifice $(99 \mathrm{ft} / \mathrm{sec}$. Flow perturbations (impingement) were produced by alternately constricting flow diameters and changing flow directions between the normal mass transfer samples in several locations, as described earlier. ${ }^{4}$

It is apparent that the impingement of the sodium flow has increased the deposition rates by a factor of four over the average rates at similar temperatures, cooling rates, and mass flow rates. The interesting factor is that the maximum deposition rates were also measured on the normal samples that were on either side of the impingement samples. Therefore, the turbulence produced by the impingement samples appears to have as great an effect as impingement itself. The other interesting fact is that the flow openings through the impingement samples produce a local sodium velocity of $\sim 15 \mathrm{ft} / \mathrm{sec}$. Therefore, the factor of four increase in deposition rate would be expected on the basis of velocity ( 15 versus $4 \mathrm{ft} / \mathrm{sec}$ ) alone.

\footnotetext{
* The term, temperature gradient, is defined as ${ }^{\circ} \mathrm{F} / \mathrm{ft}$. Test loops 8 and 9 have an effective primary cooling length of 16 feet.

The respective temperature gradients in these 16 feet are $-31^{\circ} \mathrm{F} / \mathrm{ft}$ at $3 \mathrm{gpm}$ and $-20^{\circ} \mathrm{F} / \mathrm{ft}$ at $6 \mathrm{gpm}$.
} 


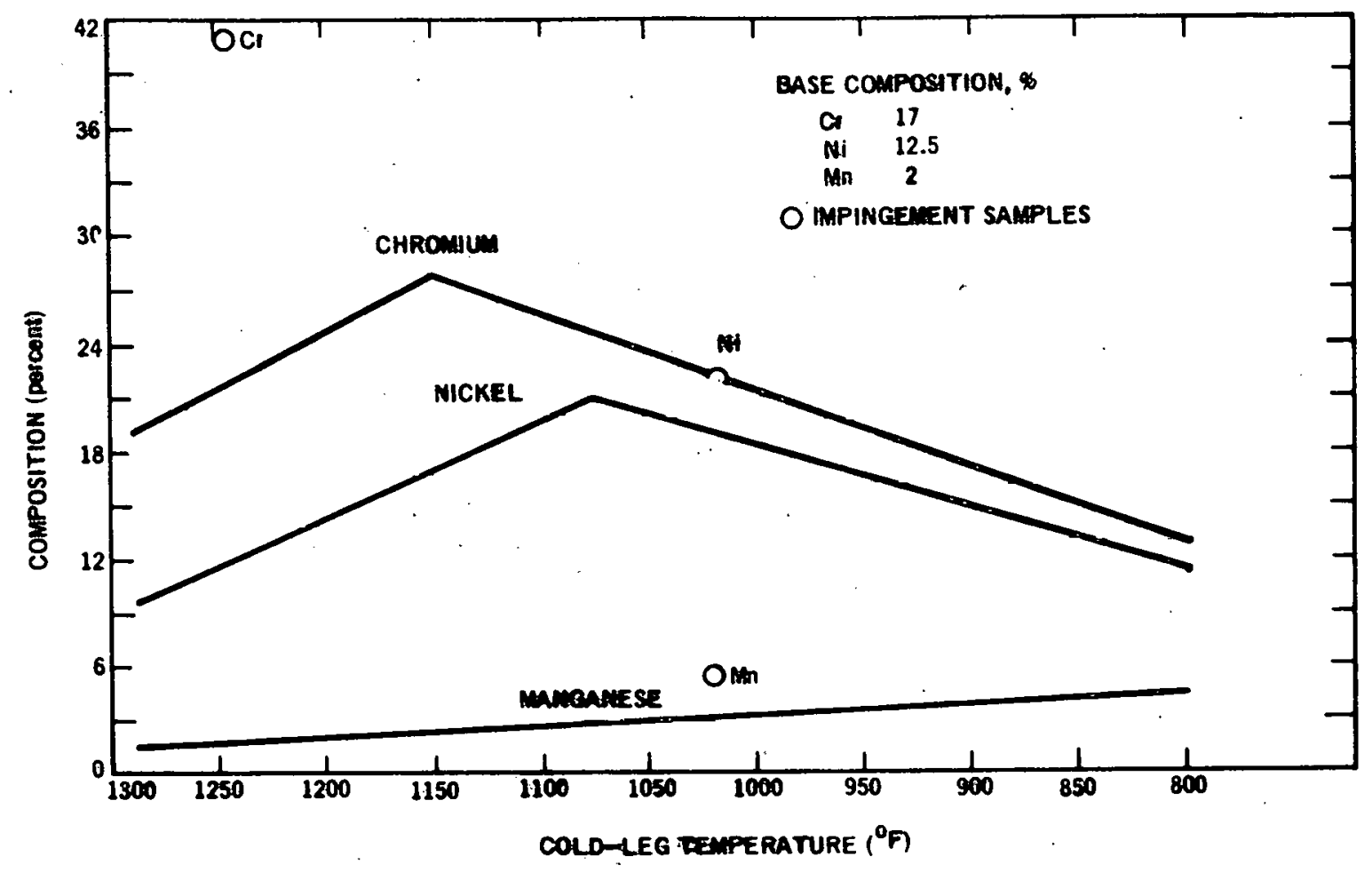

Figure 3.4. Concentration versus Temperature, 3 and $6 \mathrm{gpm}$ Flow Rates (7 Runs)

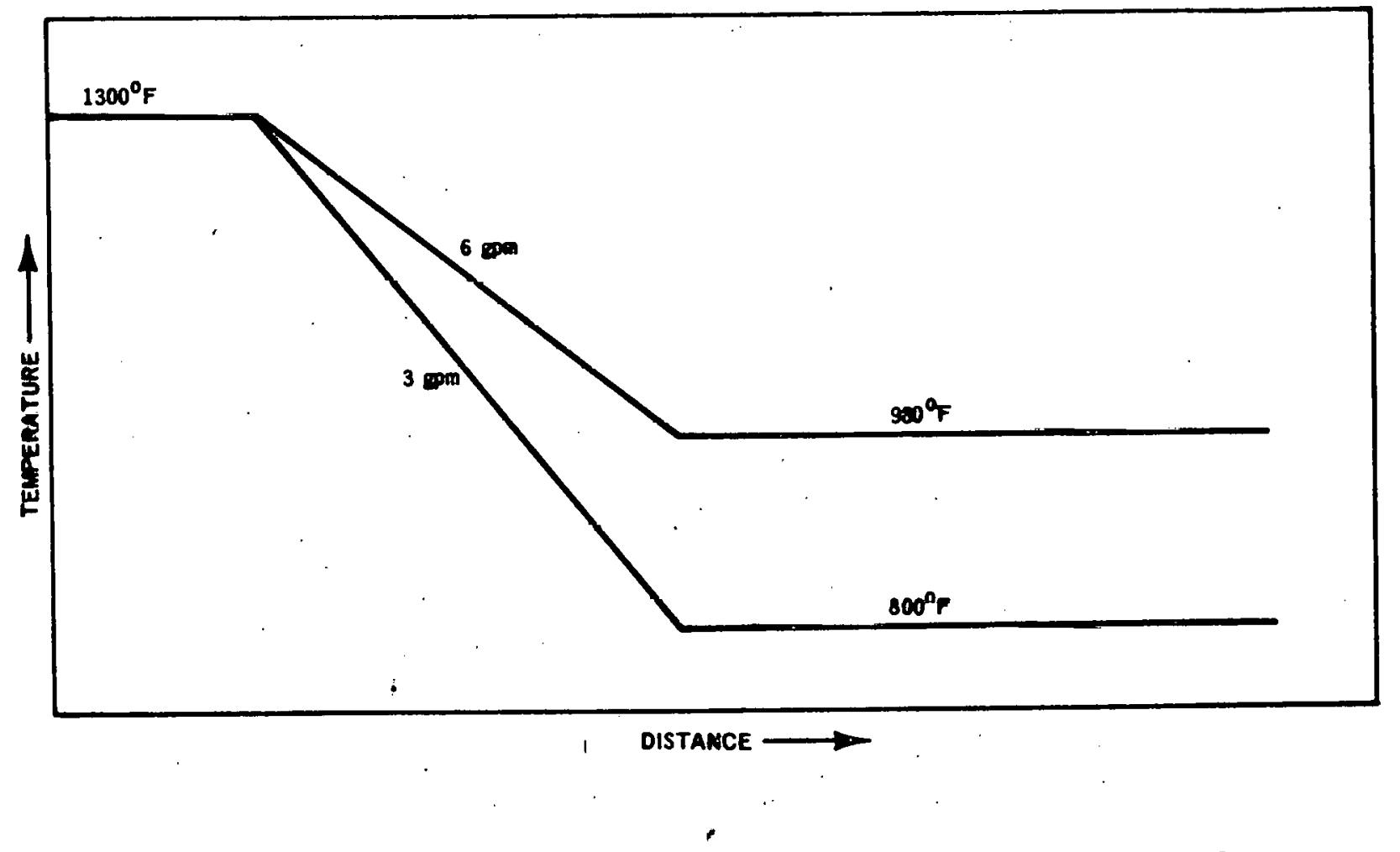

Figure 3.5. Effect of Mass Flow Rate on the Temperature Gradients in Loops 8 and 9 
The significant increase in deposition rate noted in an area of normally low deposition, produced by high velocity $(99 \mathrm{ft} / \mathrm{sec}$ ) samples (orifices), is of importance primarily because it indicates potential problem areas in the core inlet orifices and the primary pumps (impellers).

Deposition rates up to 3 mils/year have been indicated (Figure 3-3) in areas of turbulence. The duration of exposure to obtain these data was $\sim 3000$ hours, or about one-third of a year; therefore, only $\sim 1$ mil of deposit was actually measured on the walls of a sample. It is not presently known whether deposits will continue to form at this rate and, more important, to what thickness a deposit can support itself before erosion or spalling occurs. Obviously, the answers to these questions will depend on the region of deposition, since the composition and physical character will vary with position in the system.

The concentrations of the major alloying elements in the deposits are summarized in Figure 3-4. Elements such as sodium and carbon exist in the deposits up to a total of $10 \%$, with the remainder being iron. The elemental concentrations do not appear to be affected by the differences in temperature gradient occurring in the test loops. However, it can be seen that impingement, or degree of turbulence, does affect the elemental ratios.

The use of the data in Figure 3-4 is straightforward. After the respective deposition rates (or amounts of deposit) are calculated for the various regions of the FFTF reactor system, the masses of the major radioactive elements in these regions can be directly calculated from the data in Figure 3-4.

The radioactive isotopes of major consequence are:

$\begin{array}{lll}\mathrm{Co}^{59}(\mathrm{~N}, \gamma) & \mathrm{Co}^{60} & 5.3-\text { year half-life } \\ \mathrm{Fe}^{54}(\mathrm{~N}, \mathrm{P}) & \mathrm{Mn}^{54} & 314 \text {-day half-life } \\ \mathrm{Ni}^{58}(\mathrm{~N} ; \mathrm{P}) & \mathrm{Co}^{58} & 71 \text {-day half-life }\end{array}$

The isotopes chromium-51 and iron-59 have still shorter half-lives and should not pose a problem for shutdown times approaching a year. As shown in Figure 3-4, manganese is deposited throughout the system, reaching a peak at the lower temperatures. Manganese-54 will be a problem throughout the primary system of the reactor. Since manganese probably moves as elemental manganese, the calculation of amounts should be straightforward. It is not known whether cobalt will move and deposit in a manner similar to nickel; however, the assumption is made here that it will, since the two elements are almost inseparable in process metallurgy. Based on this assumption and Figure.3-4. the major deposition of cobalt -60 and -58 will occur in the lower temperature region of the IHX. Since nickel moves as elemental nickel, the prediction of the distribution of cobalt deposited is straightforward .

\subsubsection{Limitations}

The calculated deposition rates are assumed to continue for the life of the plant (20 years): No allowance for erosion and spalling of the deposition was made.

This simple model was used because it represents the present state of the art. While it is based upon test results, proper interpretation is quite difficult bccausc:

- The laboratory tests were brief and the deposits were consequently thin.

- The test loop maximum temperature and the temperature differentials may not correspond to eventual FFTF operating conditions.

- There is no general way to estimate whether small loop data (addressed exclusively to system variables) are adequate to estimate the mass transport that will occur in a large LMFBR primary loop. The effects of changes in total volume, ratio of hot-leg to cold-leg surface area, volume-to-surface-area ratio, and residence time cannot presently be factored into the estimates of mass transfer. Tests are in progress to evaluate these factors.

Estimates of the deposition which occurs around the primary loop of a large LMFBR are based on the short-term, small-loop test data. The confidence of such estimates will increase with more data from tests designed to answer the following questions:

- How do variables independent of the system affect deposition?

- Will deposits continue to grow at the initial rate? To what thickness can a deposit grow and still support itself before erosion and spalling equal the deposition rate?

- Initial deposition has been shown to be a function of the local velocity. Since corrosion and spalling are also functions of velocity, will the relative deposition thickness around the loop tend to even out in the long run? 


\subsection{RADIOACTIVE MASS TRANSPORT DATA}

\subsubsection{Radioisotope Transport and Deposition in Flowing Sodium, BNWL}

Shannon ${ }^{5}$ predicts that material removed from the core of the FFTF operating at $1200^{\circ} \mathrm{F}$ bulk sodium temperature, $25 \mathrm{ft} / \mathrm{sec}$ sodium velocity, and $10 \mathrm{ppm}$ oxygen will contain large amounts of radioisotopes produced from irradiation of the cladding:

$$
\begin{aligned}
& \mathrm{Cr}^{51} \text {.27.8-day half-life . . . . . . . . . . . . . . . . } 2 \mathrm{Ci} / \mathrm{cm}^{3} \\
& \mathrm{Co}^{58}, 71 \text {-day half-life . . . . . . . . . . . . . . . . . . } 31 \mathrm{Ci}^{2} \mathrm{~cm}^{3} \\
& \mathrm{Co}^{60}, 1913 \text {-day half-life . . . . . . . . . . . . . . . . } 2 \mathrm{Ci} / \mathrm{cm}^{3} \\
& \mathrm{Mn}^{54} \text {, 313-day half-life . . . . . . . . . . . . . . . . } 10 \mathrm{Ci} / \mathrm{cm}^{3}
\end{aligned}
$$

Brehm ${ }^{6}$ has made a study under the foregoing conditions which concludes that about $1100 \mathrm{cc}$ of material will be lost from the core and transported to other parts of the primary circuit in 1 year of operation. The isotope inventory will be $\sim 10,000 \mathrm{Ci}$, and the radiation level near the heat exchanger may exceed $100 \mathrm{R} / \mathrm{h}$, depending upon deposition conditions.

Two types of sodium loops were used in Brehm's radioisotope transport experiments: a pumped loop constructed of Type-304 stainless steel, with a 2-gpm capacity and sodium velocities ranging from $0.5 \mathrm{ft} / \mathrm{sec}$ in the heat exchanger to $40 \mathrm{ft} / \mathrm{sec}$ at the specimen location; and thermal convection loops constructed of Type-304 stainless steel, with velocities in the range of 0.2 to $0.8 \mathrm{ft} / \mathrm{sec}$. Two categories of irradiated stainless steel specimens were used:

a. . Material irradiated in a thermal flux containing chromium-51, cobalt-60, and iron-59.

b. Stock from EBR-1l (fast flux) containing mangenese-54 and small amounts of cobalt- 58 .

Tests run in both loops at $1300^{\circ} \mathrm{F}$ for 480 hours with thermally irradiated samples showed that chromium -51 and cobalt- 60 were released from the specimen, but migrated only a short distance downstream. The two isotopes were not found in the heat exchanger or the cold trap of the transport loop. Analysis of the loop sodium showed cobalt-60, chromium-51, and traces of manganese-54, indicating higher manganese-54 solubility. No iron-59 was ever found on loop piping, even though substantial amounts were present in the source tab.

A test run in the transport loop with a sample that had been irradiated in EBR-II gave different results. Manganese was released in $\sim 10$ times the amount of chromium released in the previous test, and manganese- 54 was found all over the loop, including the cold trap.

Tests in the thermal convection loops with manganese-54-bearing samples yielded results showing that both sample temperature and loop $\Delta T$ affect the transport of manganese-54.

During the course of the study, it was noted that deposited radioactive atoms diffuse into the pipe wall. The rate of penetration of chromium- 51 and manganese- 54 is roughly that predicted by diffusion theory. This indicates that the cleanup of chromium and manganese may be difficult.

In summary, the results of the study indicate that chromium- 51 and cobalt-60 do not migrate rapidly to lower-temperature regions of loop systems. Chromium -51 would probably be plated out on the top of the fuel pins just ahove the core, and might possibly decay away by the time the chromium atom is "exchanged" off the top of the fuel pin. Cobalt-58 and cobalt- 60 should behave like chromium-51. Manganese-54 is released in larger quantities and deposits throughout the test loops. Preferential deposition sites for manganese-54 were immediately downstream from the source, at minimum-temperature locations, and in cold traps. Manganese-54 will probably be trapped just downstream of the heat exchanger and in the cold trap, especially if high-velocity, high-turbulence flow conditions are present.

The results reported by Brehm for the transport of manganese- 54 are in excellent agreement with the manganese deposition patterns seen in the P.A. 15 studies. In contrast, Brehm's results for the transport of chromium.51 do not agree at all with the deposition patterris lor chromlum fuund in P.A. 16. Cobalt-6n also transports poorly, whereas nickel (thought to behave similarly to cobalt) deposits in a manner similar to chromium. Previous studies of transport and deposition of irradiated stainless steel in flowing sodium have shnwn that activity transport is not necessarily coincident with gross mass transport. ${ }^{7,8}$ Further work is necessary to define more accurately the transport of cobalt-60.

\subsubsection{Source Term Computer Program (STP.1), Al}

Atomics International has reported ${ }^{9}$ a preliminary series of parametric studies using the Source Term Computer Program (STP-1) to investigate the effects of certoin variables on the residual radiation levels produced by activated corrosion products. These studies are discussed below: 
The example system consisted of a 250-MW(t) LMFBR with an average neutron flux of $5 \times 10^{15}$ nv. An average core corrosion rate of $1 \mathrm{mil} / \mathrm{year}$ was assumed for an average hot-leg temperature of $1060^{\circ} \mathrm{F}$ and an oxygen content of $3 \mathrm{ppm}$ (cold trap temperature of $302^{\circ} \mathrm{F}$ ). The assumed corrosion rate was about four times greater than the rates based on the P.A. 15 and UK results: Chromium was assumed to corrode at twice the rate of the stainless steel constituents. This is approximately true for nickel, but certainly not for iron and manganese. The core had a surface area of $1.75 \times 10^{7} \mathrm{~cm}^{2}$, with a core coolant volume of $2.62 \times 10^{6} \mathrm{~cm}^{3}$, and a total volume of $8.51 \times 10^{8} \mathrm{~cm}^{3}$. The total flow in the primary loop was $2.4 \times 10^{5} \mathrm{gpm}$, with a bypass cold-trap flow of $250 \mathrm{gpm}$.

The primary system of the reactor was divided into five regions with the following average temperatures:

$\begin{array}{lr}\text { Hot leg } & 1060^{\circ} \mathrm{F} \\ \text { Hot half IHX } & 985^{\circ} \mathrm{F} \\ \text { Cold half IHX } & 835^{\circ} \mathrm{F} \\ \text { Cold leg } & 760^{\circ} \mathrm{F} \\ \text { Cold trap } & 302^{\circ} \mathrm{F}\end{array}$

The deposition model used in STP-1 for corrosion products assumes that partial precipitation of corrosion products will occur in those regions where the concentration of an element exceeds its solubility. The fraction of the concentration above saturation that precipitates per-unit time in such a region is the precipitation efficiency for that region. Precipitation efficiencies are then assigned for the first four regions of the primary system for the initial computations. It is not clear. how particulate corrosion products that are non-contributors to the saturation are handled in this model: Further, an efficiency is prescribed for the hot leg that should basically see zero deposition, since super-saturation is not achieved in the hot leg. After insertion of a factor into the program considering deposit re-entry into the sodium due to erosion, etc., and setting the initial coolant concentrations of chromium, nickel, iron, manganese, and cobalt equal to their solubilities at $760^{\circ} \mathrm{F}$, the following cases were considered:

a. Cold-trap efficiency $=0.006 \%$

b. Cold-trap efficiency $=100 \%$

c. Cold-trap efficiency $=10 \%$, or $100 \%$ efficiency with $1 / 10$ the reference flow rate

d. Cold-trap efficiency $=10 \%$, and corrosion product solubilities are $1 / 10$ their reference estimated values

The radiation levels calculated by STP-1 for the five primary loop regions in these four cases are high for the cold-trap as would be expected, and essentially negligible in all other regions for all except case a: In case a., the cold leg has the highest radiation level, followed by the cold trap, cold half $\mathrm{IHX}$, hot half $\mathrm{IHX}$, and the hot leg. The results for case a. are reasonable in order of region intensity, with the exception of the hot leg (discussed previously). 


\section{ACTIVITY ESTIMATES}

\subsection{FFTF OPERATING PARAMETERS AND DESIGN}

The FFTF operating parameters and the design data $10,11,12$, used to calculate the component surface areas and surface-to-volume ratios are shown in Figure 4-1 and Tables 4-1 and 4-2. The results of the calculation are shown in Table 4-3.

\subsection{EXTRAPOLATION OF P.A. 15 MASS TRANSFER DATA TO FFTF OPERATION CONDITIONS}

The P.A. 15 loop deposition data were extrapolated, as outlined in Section 3, to account for the lower average core temperature and system $\Delta T$ of the FFTF. The results of these extrapolations are shown in Figures 4-2 and 4-3. Although, in Figure 4-2, deposition rate curves are shown for sodium velocities of 2 and $4 \mathrm{ft} / \mathrm{sec}$, the $4-\mathrm{ft} / \mathrm{sec}$ curve will be utilized for the FFTF calculations because the temperature gradient of $20^{\circ} \mathrm{F} / \mathrm{ft}$ is more representative of the $\mathrm{IHX}$ in the FFTF than the $31^{\circ} \mathrm{F} / \mathrm{ft}$ gradient at $2 \mathrm{ft} / \mathrm{sec}$. For this reason, corresponding low-temperature $K 750^{\circ} \mathrm{F}$ ) isothermal deposition rate values as a function of velocity are included in Figure $4-2$ for the $20^{\circ} \mathrm{F} / \mathrm{ft}$ data.

\subsection{CALCULATION OF THE MASS TRANSFER OF THE FFTF}

The following data are calculated, using the results from subsections 4.1 and 4.2 :

a. Mass transfer rates (mils/year) for the various FFTF components

b. End-of-life, assumed to be $\mathbf{2 0}$ years, mass transfer (mils) for the various FFTF components

c. FFTF component weight changes (Ib) at end-of-life

d. Elemental makeup [i.e., weight of nickel (cobalt) and manganese] of the deposits on the various FFTF components at end-of-life.

\subsubsection{Mass Transfer Rates}

The deposition/corrosion rates shown in Figure 4-2 are varied directly with the sodium velocity of the FFTF components listed in Table 4-3. As a conservative estimate of mass transfer rates, only the upper band of the $4 \mathrm{ft} / \mathrm{sec}$ velocity curve is used. For example, the deposition rate of a FFTF component operating at $900^{\circ} \mathrm{F}$ and $20 \mathrm{ft} / \mathrm{sec}$ would be calculated as follows:

From Figure 4-2, the deposition rate at $900^{\circ} \mathrm{F}$ is $0.104 \mathrm{mil} /$ year at $4 \mathrm{ft} / \mathrm{sec}$.

At $20 \mathrm{ft} / \mathrm{sec}$, the rate would be $0.104 \times 20 / 4=0.520 \mathrm{mil} /$ year. ${ }^{*}$

The results are shown in Table 4-4. The temperature and corrosion rate for the fuel pins, listed in Tables 4-3 and 4-4. are calculated separately. The calculations are shown in Appendix A.

\subsubsection{End-of-Lifa Mass Transfer}

The deposition/corrosion rates calculated in subsection 4.3.1 are considered to remain constant for the 20-year lifetime of the FFTF. No allowance is made for the possible spalling or erosion of the deposits. The calculated end-of-life deposit thickness or corrosion allowance for the various FFTF components is shown in Table 4-4.

\subsubsection{End-of-Life Weight Changes}

The component weight changes are calculated assuming a deposition density equal to stainless steel. Therefore, the calculation is performed by converting the thickness changes in subsection 4.3.2 to weight/unit area $\left(2000 \mathrm{mg} / \mathrm{dm}^{2}{ }^{2}-1 \mathrm{mil}\right)$ and multiplying by the components surfare area (Table 4-3). The results are listed in Table 4-4, which shows that the amount of corrosion products are substantially greater than the mass deposited $11141 \mathrm{lb}$ lost and $633 \mathrm{lb}$ gaincd). There are various reasnns for this discrepancy, the most important being the limitations of the present state-of-the-art listed in subsection 3.2.1. For the purpose of this analysis, the difference will be assumed to have been collected by the primary system cold traps.

\subsubsection{Weight of Nickel (Cobalt) and Manganese}

Cobalt and manganese are the radioactive isotopes of interest in the activity estimates. It is assumed that cobalt moves in a manner similar to nickel in a flowing sodium system. Therefore, the calculations are limited to nickel and manganeso:

\footnotetext{
- If this extrapolation had been done on the basis of $N_{R}$, the deposition rate predicted in the reactor would have been smaller.
} 
Table 4-1

FFTF CORE AND PRIMARY SODIUM SYSTEM DESIGN DATA USED

System Parameter

1. Reactor Core

Power

Temperature

Inlet

Outlet

Flow

Peak Flux

Drivers

Safety Rods

Control Rods

Shim Rods

2. Reactor Vessel.

Material

Overall Height

Overall Diameter

Inlet Nozzles

Quantity

Size (diameter)

Inlet/Outlet Temperature

Outlet Nozzles

Quantity

Size (diamieter)

3. Heat Transport System

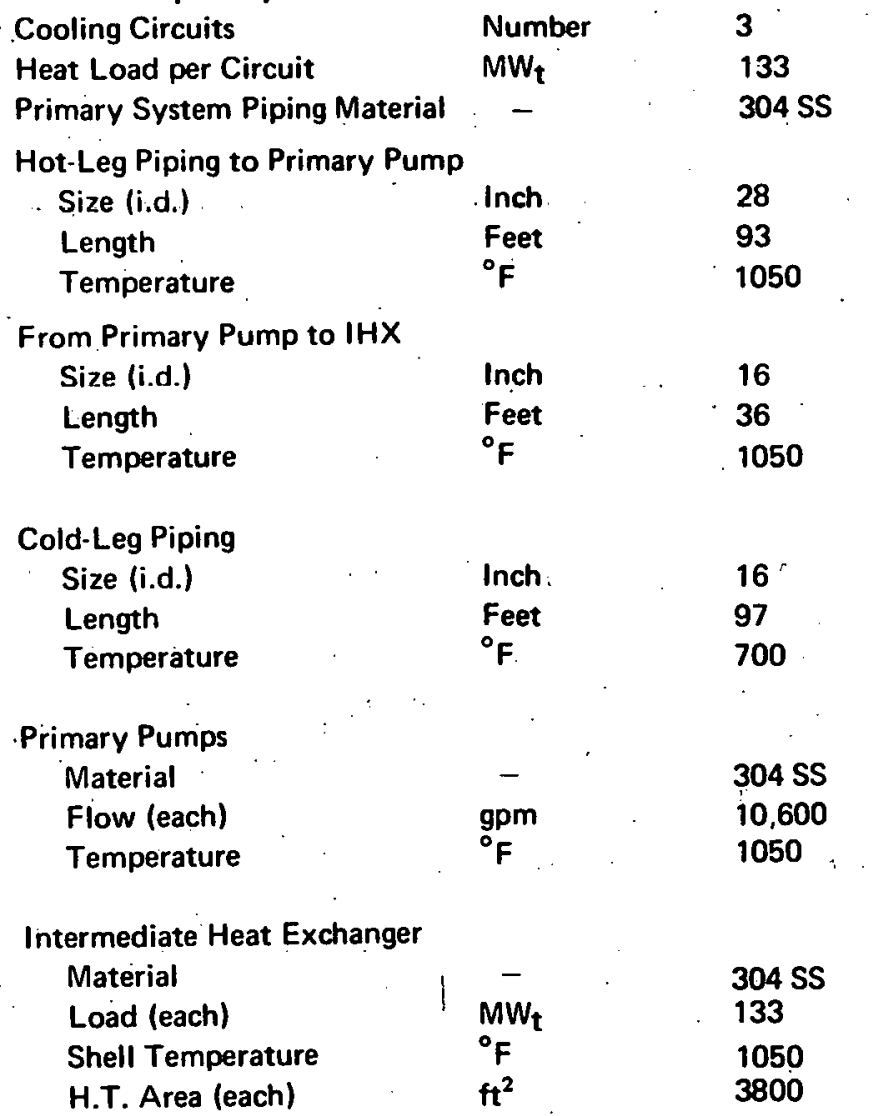

Value

400

${ }^{\circ} \mathrm{F} \quad 700$

${ }^{\circ} \mathrm{F} \quad 1050$

$10^{6} \mathrm{lb} / \mathrm{h} \quad 12.9$

$\mathrm{n} / \mathrm{cm}^{2}$-sec $\quad 7 \times 10^{1 \mathrm{~s}}$

Number $\quad 82$

Number 3

Number $\quad 12$

Number $\quad 7$

\begin{tabular}{ll}
\multicolumn{1}{c}{} & 304 SS \\
ft-in. & $43-2$ \\
ft-in. & $18-0$ \\
Number & 3 \\
$\begin{array}{l}\text { Inch. } \\
{ }^{\circ} \mathrm{F}\end{array}$ & 16 \\
& $700 / 1050$
\end{tabular}

Number 3

Inch 28

Inch

28

2


Table 4-2

FFTF FUEL DESIGN

\section{Section}

Inlet Section

Lower Shielding(a)

Lower Reflector

Core Region (b)

Upper Reflector

Gas Plenum

Contingency and Miscellaneous

Upper Shield and Grapple
Total Channel

Height (inches)
Fuel Pin Height

(inches)
Shielding Pin

Height (inches)

Total

$\begin{array}{rc}18 & - \\ 42 & - \\ - & 8.6 \\ 36 & 36 \\ 6 & 6 \\ 36 & 36 \\ 24 & 24 \\ 6 & 6 \\ 168 & 86.6\end{array}$

15

-

-

$-$

-

-

$-$

15

(a) Separate shielding pins (0.375 in. $0 . d ., 91$ pins/bundle, 1.15 p/d).

(b) Fuel bundles consist of 217 pins, 0.230 in. $0 . d$., p/d 1.25.

Table 4-3

SUMMARY OF FFTF PRIMARY SYSTEM DATA (ALL LOOPS)

$\quad$ Components
Primary Tank
Cold-Leg Piping
Inlet Plenum
Flow Distribution Casting
Bottom Shield
Fuel Pins
Assembly Above Fuel
Shield Rod-Guide Tube Area
Hot-Leg Piping (Reactor to Pump)
Hot-Leg Piping (Pump to IHX)
Primary Pump Impeller
Top-Half IHX
Bottom-Half IHX

(a) Calculations in Appendix A.

$\begin{array}{cr}\begin{array}{c}\text { Surface to } \\ \text { Volume Ratio } \\ \left(\mathbf{f t}^{-1}\right)\end{array} & \begin{array}{r}\text { Area } \\ \left(\mathrm{ft}^{2}\right)\end{array} \\ & \\ \sim 0.30 & 2500 \\ 0.80 & 1160 \\ 0.35 & 630 \\ 5 & 110 \\ 23 & 765 \\ 24 & 7700 \\ 3 & 300 \\ 0.5 & \sim 400 \\ 0.45 & 1920 \\ 0.80 & 430 \\ 1 & \sim 30 \\ 3.6 & 5700 \\ 3.6 & 5700\end{array}$


Table 4-4

SUMMARY OF FFTF PRIMARY SYSTEM MASS TRANSFER (ALL LOOPS)

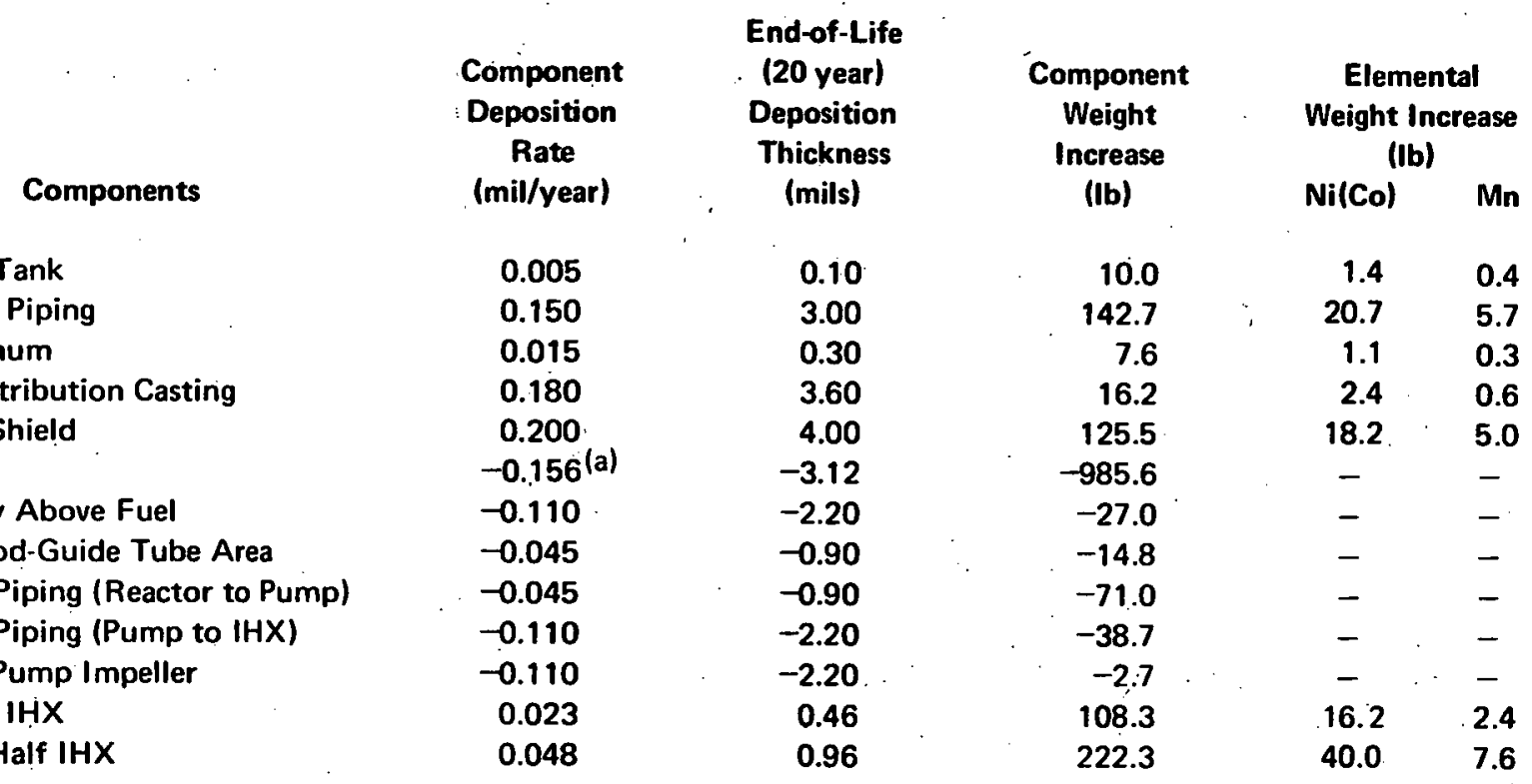

(a) Calculations in Appendix A.

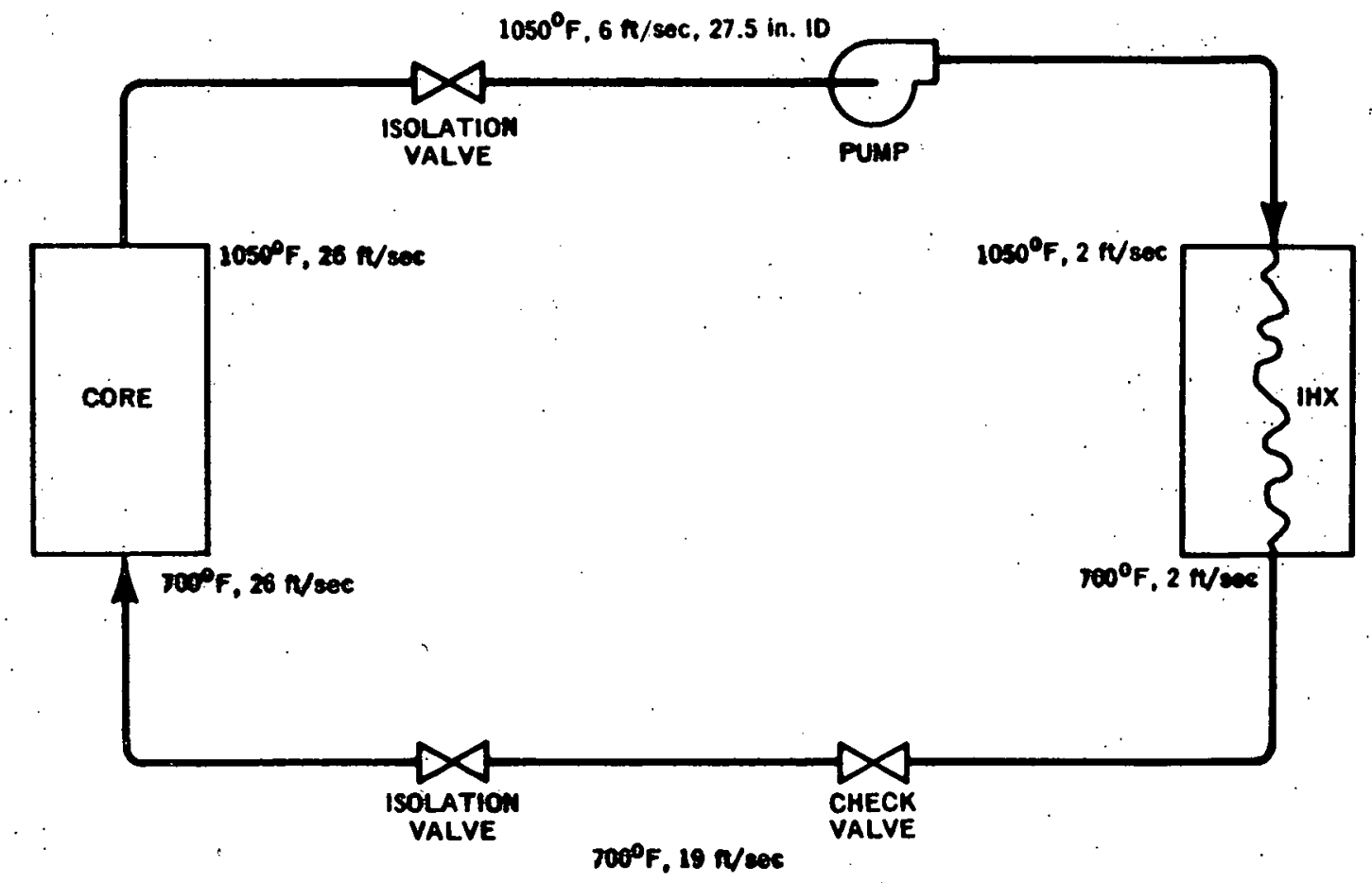

Figure 4-1. Schematic of an FFTF Loop Showing the Operating Parameters Assumed 


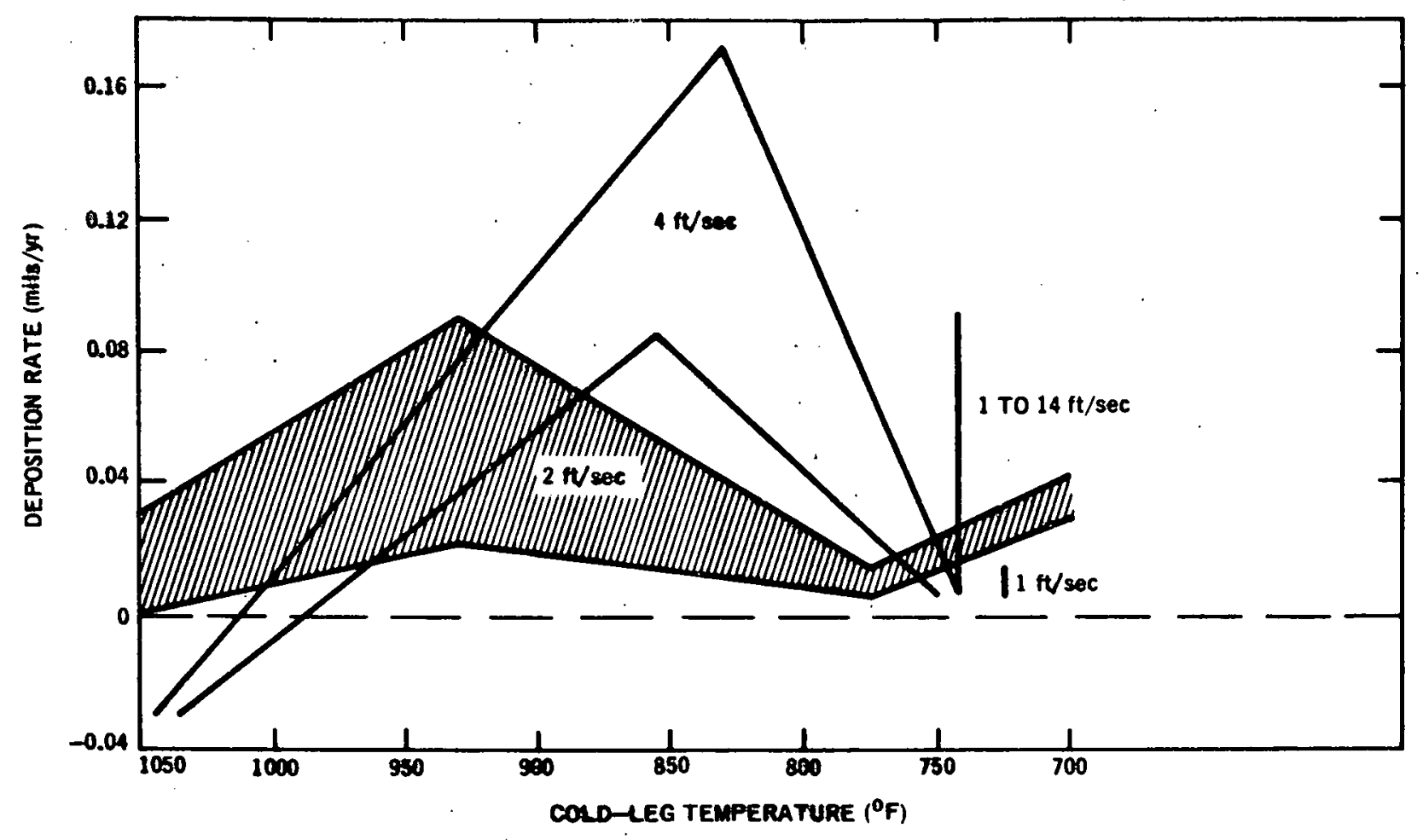

Figure 4-2. Deposition Rate versus Temperature for FFTF System Conditions

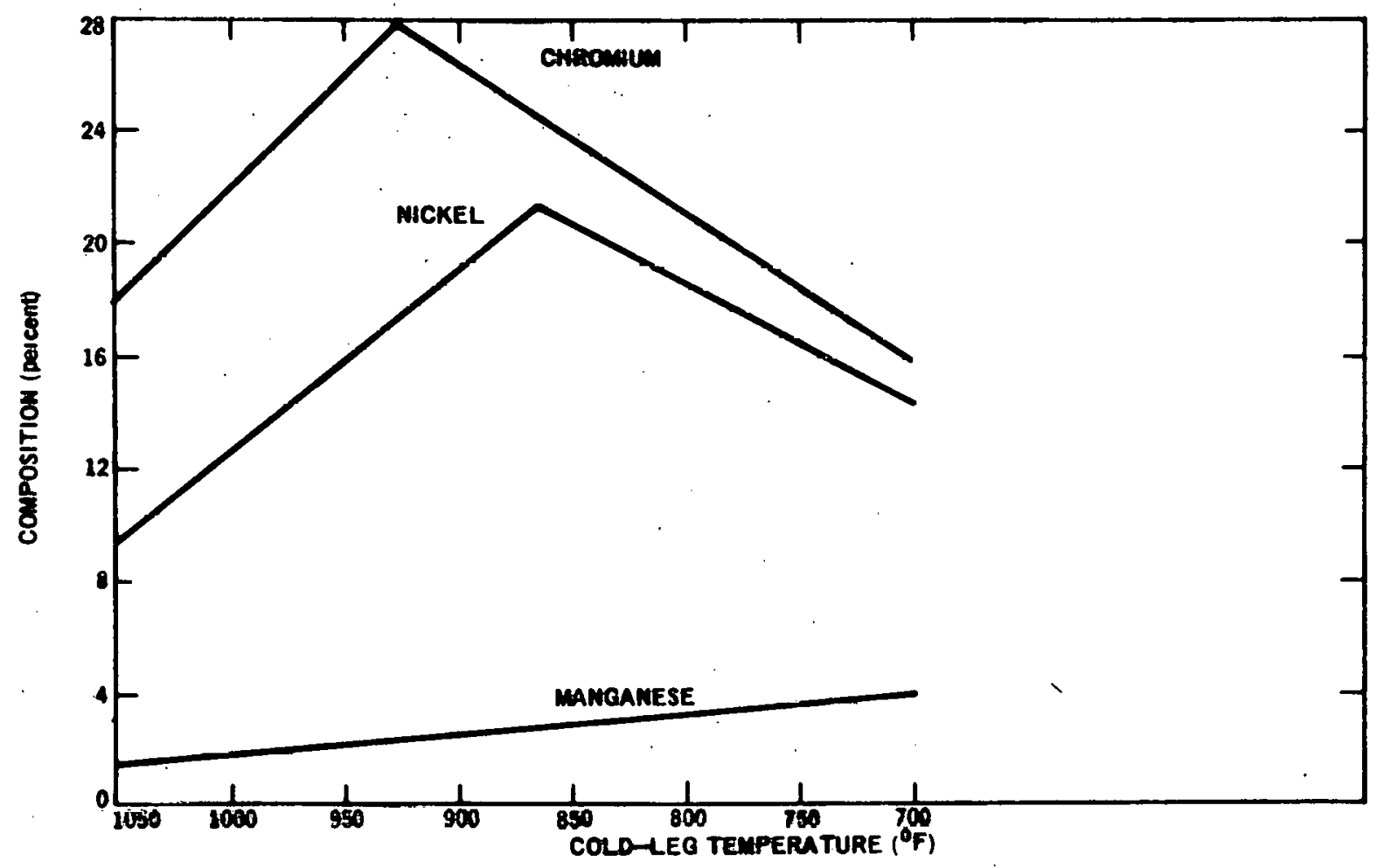

Figure 4-3. Deposit Composition versus Temperature for FFTF System Conditions 
With the aid of Figure 4-3, recommendations from Section 3, and the component weight changes calculated in subsection 4.3.3, the amounts of nickel and manganese present on the various FFTF components are calculated on the basis of stoichiometry as follows:

Component Weight Change $\dot{X}$ Percent $\mathrm{Ni}$ or $\mathrm{Mn}$ at Component Temperature

$=$ Weight of $\mathrm{Ni}(\mathrm{Co})$ or $\mathrm{Mn}$ in the Component

The results are shown in Table. 4-4.

\subsection{CALCULATION OF THE ACTIVITY OF COBALT-58, COBALT-60, AND MANGANESE-54 RELEASED AND DEPOSITED}

The calculation of cobalt-58, cobalt-60, and manganese-54 activity concentrations was performed in each of four regions: core, axial reflector, fission gas plenum, and radial reflector. - This was part of an agreement made during a meeting between the AEC, WADCO, and GE-BRDO, which is summarized in Appendix B. system: 13

The following equation was used to determine cladding corrosion product radioactivity in the primary coolant

$$
A_{i}=\phi \sigma_{i} W\left[\frac{1}{\lambda_{i}}-\left(\frac{1}{\lambda_{i}}+T\right) e^{-\lambda_{i} T}\right] \text {. }
$$

where

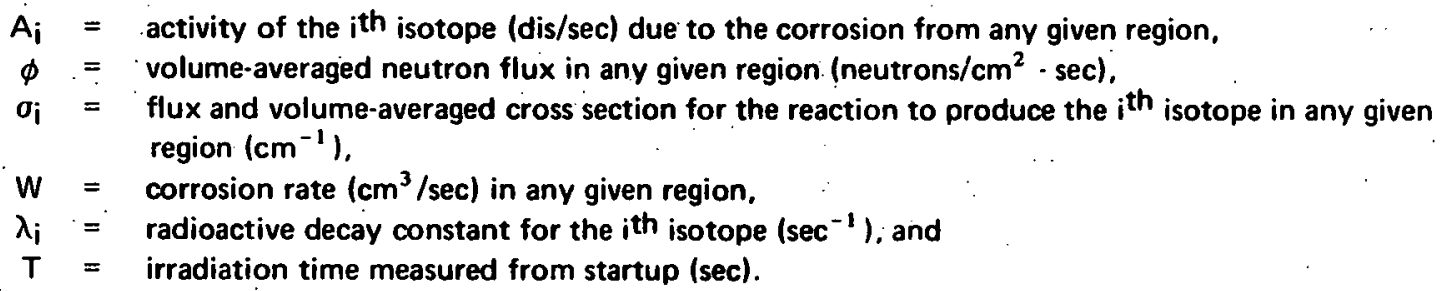

In making these computations, the assumption was made that the cobalt-58 and manganese-54 isotopes would reach equilibrium formation-decay conditions somewhere in the primary coolant system. However, the 5.3-year half-life cobalt-60 will only approach equilibrium concentration during the assumed 20-year irradiation period: For the cobalt-60 computation, the activity was calculated for time steps (or cycles) of 240 days until the facility lifetime (20 years) was reached. The latter calculations assumed that the core, reflectors, and fission gas plenum were changed each 240 days.

The cladding material was assumed to be Type-316 stainless steel, having the following elemental composition:

$\begin{array}{lc} & \text { Wt \% } \\ \mathrm{Fe} & 64.85 \\ \mathrm{Cr} & 17.0 \\ \mathrm{Ni} & 12.5 \\ \mathrm{Mo} & 2.5 \\ \mathrm{Mn} & 2.0 \\ \mathrm{Si} & 1.0 \\ \mathrm{Co} & 0.10 \\ \text { Others } & 0.05 \\ \text { Total } & 100.00\end{array}$

The volume-averaged flux and cross sections (Table 4-5) were supplied by WADCO, ${ }^{14}$ per Appendix B.

The total corrosion mass of 986 pounds for the fuel pins (Table 4-4) had to be divided between the four regions previously discussed. Using the heights from Table 4-2 and the radii supplied by WADCO. ${ }^{14}$ volumes, and consequently volume fractions, were calculated for each of the four regions. From Figure A-1, corrosion rates, and consequently corrosion rate fractions, were calculated for each of the four regions. Combining the volume and corrosion rate 
fractions and normalizing to a base of one, produced a decimal factor of the total corrosion mass for each of the four regions. The results are shown in Table 4-6. The use of a volume relationship as opposed to a surface area relationship is permissible if the pin diameters and spacing of the pins in the four regions are approximately equal. Making this assumption greatly simplifies the calculation.

The quantities of radio-corrosion product activity, shown in Table 4-7, were calculated in the FFTF primary coolant following operation for 20 years at a rated power of $400 \mathrm{MW}(\mathrm{t})$ and a load factor of 0.75 .

Table 4-5

VOLUME-AVERAGED FLUX AND CROSS SECTIONS

Region

Core

Axial Reflector

Fission Gas Plenum

Radial Reflector $\bar{\phi}$

$4.2 \times 10^{15} \mathrm{nv}$

$1.87 \times 10^{15} \mathrm{nv}$

$0.292 \times 10^{15} \mathrm{nv}$

$0.889 \times 10^{15} \mathrm{nv}$

\begin{tabular}{|c|c|c|}
\hline & $\bar{\sigma}$ (barns) & \\
\hline $\mathrm{Co}^{59}(\mathrm{n}, \gamma) \mathrm{Co}^{60}$ & $\mathrm{Fe}^{54}(\mathrm{n}, \mathrm{p}) \mathrm{Mn}^{54}$ & $\mathrm{Ni}^{58}(n, p) \mathrm{Co}^{58}$ \\
\hline
\end{tabular}

0.122

0.0092

0.0136

1.730

0.0028

0.0045

3.470

0.0004

0.0007

1.949

0.0017

0.0028

Table 4-6

RESULTS OF DISTRIBUTING TOTAL MASS (POUNDS IN 20 YEARS) BETWEEN FOUR REGIONS OF THE FFTF

Region

Core 151

Axial Reflector

Fission. Gas Plenum

470

Radial Reflector

$\frac{287}{986}$

Table 4-7

RADIO-CORROSION PRODUCT ACTIVITY RELEASED TO THE FFTF PRIMARY COOLANT SYSTEM (20 YEARS)

Origin
Core

Axial Reflector

Fission Gas Plenum

Radial Reflector

Total

$$
\mathrm{Mn}^{54}
$$

(314 da)

327.2 curies

22.9 curies

3.1 curies

24.3 curies

377.5 curies

$$
\mathrm{Co}^{58}
$$$$
\text { (71 da) }
$$

$\mathrm{Co}^{60}$

(5.3 yr)

724.2 curies

55.1 curies

8.1 curies

60.0 curies

847.4 curies
109.5 curies

356.9 curies

673.6 curies

703.4 curies

1843.4 curies 
Although 986 pounds of corrosion product contributed to the activity release calculations, a total of 1141 pounds of corrosion product existed for deposition purposes. (Table 4-4). As stated previously, only 633 pounds of deposit are accounted for in the primary system of the FFTF. Therefore, the remaining 508 pounds of deposition products are assigned to the cold trap.

The "key". components of interest in the FFTF primary system, where activity calculations due to deposition are made, were supplied by WADCO, ${ }^{15}$ per Appendix B. These components are the hot-leg piping, IHX, cold-leg piping, primary pump, and cold trap. As seen in Table 4-4, the hot-leg piping and primary pump are corrosion areas; therefore, no activity calculations were made. The amounts of cobalt and manganese deposited in the IHX (top and bottom halves are treated separately) and cold-leg piping are shown in Table 4-4. The 508 pounds of deposit in the cold trap are assumed to consist of $\mathbf{4 2 . 6}$ pounds of cobalt and 0.8 pounds of manganese. This assumption is based on the 1141 pounds of deposition product being of stoichiometric composition (12.5 wt\% nickel-cobalt and $2.0 \mathrm{wt} \%$ manganese), since the corrosion is assumed to be stoichiometric. Therefore, there is 142.6 pounds of cobalt and 22.8 pounds of manganese, and the difference between those values and the totals in Table 4-4 is assigned to the cold trap. From the amounts of cobalt and manganese deposited in the three components, the relative percentages deposited, based on the total cobalt and manganese in the FFTF deposit, are calculated (Table (4-8).

The activity determinations of cobalt-58, cobalt -60 and manganese-54 in the three components are based on the assumption that the total curies of each isotope released will be deposited in the ratio of the percentages shown in Table 4-8. As an example, $11.4 \%$ of the total curies of cobalt-58 (847.4) and cobalt 60 (1843.4) (Table 4.7) will be deposited in the top half of the IHX. The results for each one of the three component loops are shown in Table 4-9.

Table 4.8

PERCENTAGE IN COMPONENT OF TOTAL COBALT AND MANGANESE DEPOSIT

\begin{tabular}{|c|c|c|c|c|}
\hline \multirow[b]{2}{*}{ Element } & \multicolumn{2}{|c|}{. $\mathrm{IHX}$} & \multirow[b]{2}{*}{ Cold-Leg Piping } & \multirow[b]{2}{*}{ Cold Trap } \\
\hline & Top Half & Bottom Half & & \\
\hline Cob & 11.4 & 28.0 & 14.5 & 30.0 \\
\hline Manganese & 10.5 & 33.3 & 25.0 & 3.5 \\
\hline
\end{tabular}

Table 4.9

RADIO-CORROSION PRODUCT ACTIVITY DEPOSITED IN ONE LOOP OF THE FFTF PRIMARY COOLANT SYSTEM (20 YEARS)

\begin{tabular}{|c|c|c|c|}
\hline & $\begin{array}{c}M n^{54} \\
(314 \mathrm{da})\end{array}$ & $\begin{array}{c}C o^{58} \\
(71 \mathrm{da})\end{array}$ & $\begin{array}{c}\mathrm{Co}^{60} \\
(5.3 \mathrm{yr})\end{array}$ \\
\hline IHX-Top Half & 13.2 curies & 32.2. curies & 70.0 curies \\
\hline -Bottom Half & 41.9 curies & 78.8 curies & 171.4 curies \\
\hline Cold-Leg Piping & 31.3 curies & 40.7 curies & 88.5 curies \\
\hline Cold Trap & 4.5 curies & 84.8 curies & 184.3 curies \\
\hline
\end{tabular}

\subsection{CALCULATION OF THE dOSE RATE AT THE "KEY" COMPONENTS}

Estimates of the radiation intensity at 2 feet from the key components in the FFTF primary loop have been made. ${ }^{16}$ To determine the normalized intensity, the source in all cases is assumed to be 100 curies of the radioactive isotope uniformly distributed within the component. The normalized radiation intensities are based on the geometry factors of the components, which include sodium volume percentages of 80,100 , and 97.5 for the IHX, cold-leg piping, and cold trap, respectively. The pertinent normalized intensities are listed in Table 4-10.

The calculation of the dose rates for the components is then the curies for each isotope (Table 4.9) divided by 100, and multiplied by the normalized intensity for the particular isotope and component (Table 4-10). The results after 20 years are shown in Table 4-11. The FFTF primary coolant system consists of three separate loops, and the values in Table 4-11 apply to one loop. The buildup of dose rate with operating time is shown in Figure 4-4. It is interesting to note that the majority of the dose rate is accumulated within the first 5 years. On the basis of the assumptions made by WADCO, contact maintenance would not be possible in the $1 \mathrm{HX}(5.5 \mathrm{R} / \mathrm{h})$, cold-leg piping 
( $50 \mathrm{R} / \mathrm{h}$ ), or the cold trap (45 R/h) after 20 years. In fact, only very limited access and maintenance would be possible on the IHX during the initial year of operation where the dose rate would be $\sim 1 \mathrm{R} / \mathrm{h}$. In addition, contact maintenance cannot be realistically performed on the tube bundles if they are in a shell with or without sodium. The increase in the radiation intensities for the $\mathrm{IHX}$ with the tube bundles removed from the shell and drained results in a dose rate of $\sim 73 \mathrm{R} / \mathrm{h}$ after 20 years.

The consequence of the total amount of deposition products being distributed throughout the primary coolant system, with none assigned to the cold trap, would be an $80 \%$ increase in the respective base rates of the IHX and cold-leg piping. This would result in maximum values of $\sim 130 \mathrm{R} / \mathrm{h}$ in the $\mathrm{IHX}$ and $90 \mathrm{R} / \mathrm{h}$ in the cold-lea Dipina.

All of the results given in this section assume the corrosion rates based on the temperature and position dependence illustrated by Figure A-1. These results correspond to a hot channel coolant exit temperature of $1100^{\circ} \mathrm{F}$. Figure 4-5 illustrates the effect on corrosion rates of an increase in the hot-channel temperature from $1100^{\circ} \mathrm{F}$ up to $1300^{\circ} \mathrm{F}$. Since the radio-corrosion product activity in the primary system is directly proportional to the corrosion rate, Figure 4.5 also illustrates the radio-corrosion product dose rate dependence on increasing hot-channel temperature in the primary system.

Table 4-10

\section{NORMALIZED RADIATION INTENSITY AT 2 FEET FROM THE SURFACE $(\mathrm{R} / \mathrm{h})^{(\mathrm{a})}$}

$\begin{array}{ccccc}\text { Isotope } & \mathrm{IHX}(\mathbf{b}) & \mathrm{IHX}(\mathrm{c}) & \text { Cold-Leg Piping } & \text { Cold Trap } \\ & & & & \\ \mathrm{Mn}-54 & 0.7 & 2.4 & 14.0 & 6.2 \\ \text { Co-58 } & 0.8 & 2.6 & 15.7 & 6.9 \\ \text { Co-60 } & 2.7 & 8.8 & 44.5 & 20.9\end{array}$

(a) Calculation based on source of 100 curies of each of the given isotopes uniformly distributed within the component indicated.

(b) The values are based on the tube bundles remaining inside the shell and full of sodium.

(c) The values are based on the tube bundles remaining inside the shell and the sodium drained.

If the tube bundles are removed, the radiation intensities and dose rates at 2 feet will be greater by a factor of $\sim 4$.

Table 4-11

DOSE RATES (AFTER 20 YEARS) OF THE KEY COMPONENTS IN ONE LOOP OF THE FFTF AT 2 FEET FROM THE SURFACE (R/h)

$\begin{array}{lcccc} & \mathrm{Mn}^{54} & \mathrm{Co}^{58} & \mathrm{Co}^{60} & \text { Total } \\ \begin{array}{l}\text { IHX-Tube Bundles in Shell with Sodium } \\ \text { Top Half }\end{array} & & & & \\ \begin{array}{l}\text { Bottom Half } \\ \text { IHX-Tube Bundles Drained }\end{array} & 0.09 & 0.26 & 1.89 & 2.24 \\ \quad \begin{array}{l}\text { Top Half } \\ \quad \text { Bottom Half }\end{array} & 0.29 & 0.63 & 4.63 & 5.55 \\ \begin{array}{l}\text { IHX-Tube Bundles Drained and Removed } \\ \text { Top Half }\end{array} & 0.32 & 0.84 & 6.16 & 7.32 \\ \quad & 1.01 & 2.05 & 15.08 & 18.14 \\ \quad & 1.24 & 3.38 & 24.65 & \\ \text { Bottom Half } & 3.98 & 8.19 & 60.38 & 72.55 \\ \text { Cold-Leg Piping } & 4.38 & 6.39 & 39.38 & 50.15 \\ \text { Cold Trap } & 0.28 & 5.85 & 38.52 & 44.65\end{array}$




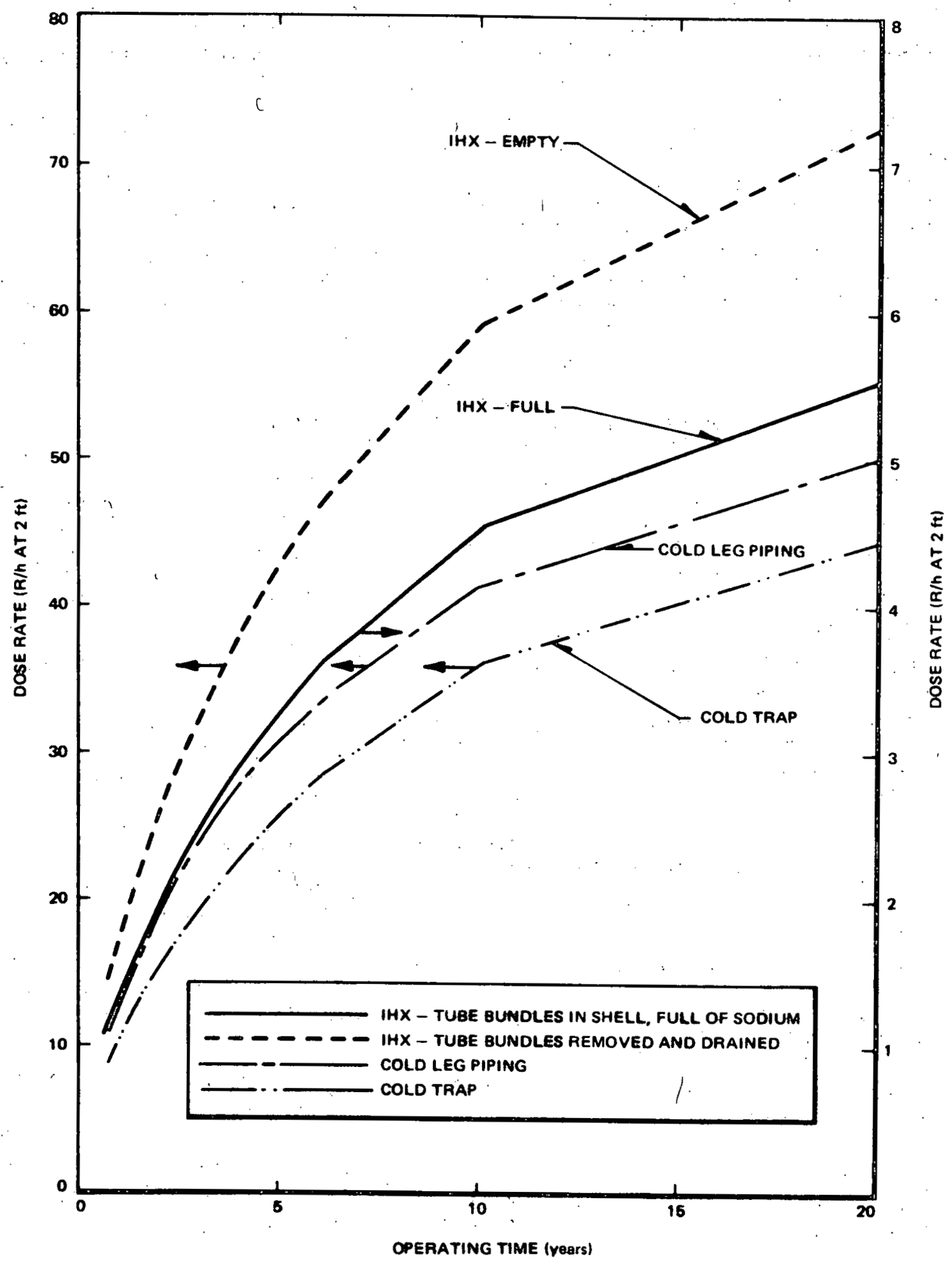

Figure 4-4. Buildup of Radioactivity in the FFTF Primary System with Uniform Depositon and 0.10 wt \% Cobalt in the Core Materials 


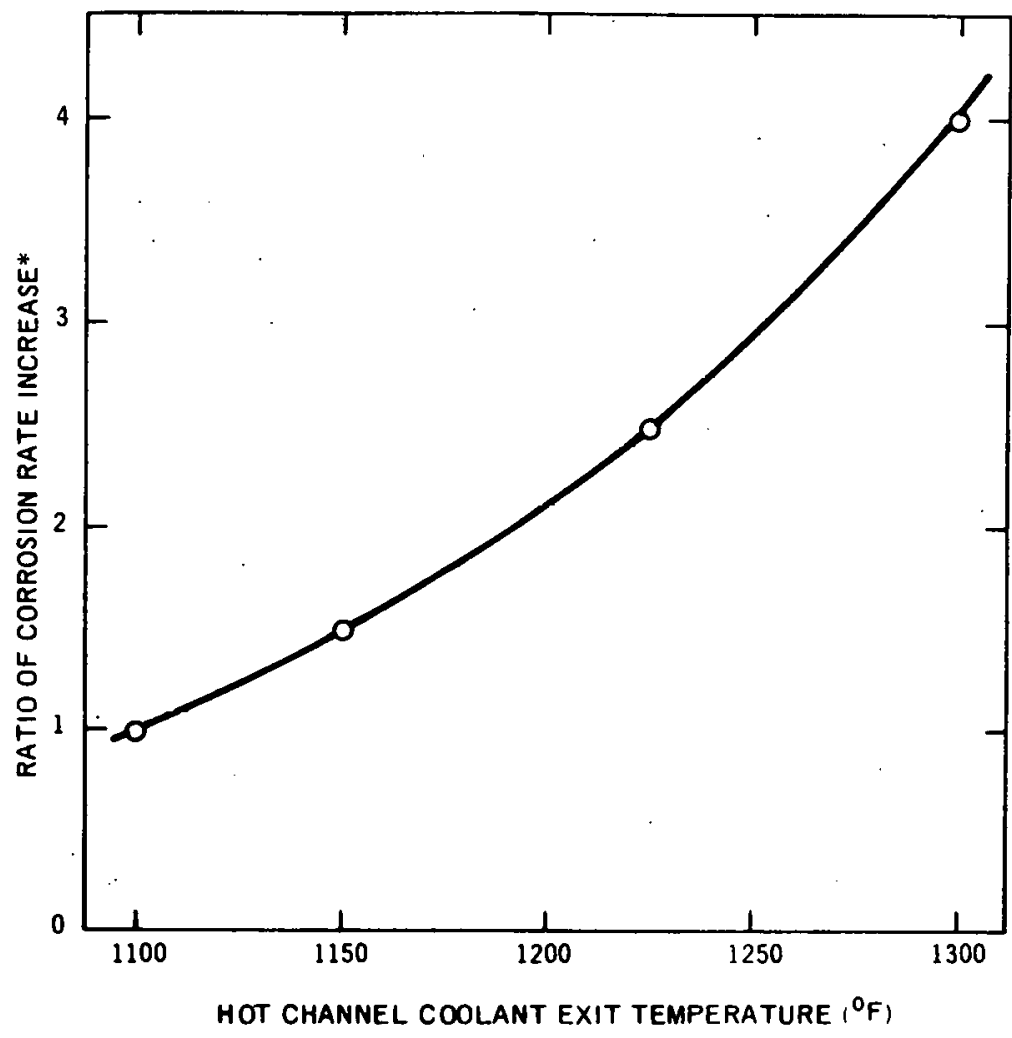

* also the Ratio of the INCREASE IN THE RADIO-Corrosion PRODUCT CONCENTRATION IN THE PRIMARY COOLANT SYSTEM AND'THE DOSE RATES AT KEY COMPONENTS

Figure 4-5. Effect of Increasing Hot Channel Coolant Exit Temperature on the Corrosion Rate of Type-316 Stainless Steel 


\section{RECOMMENDED RESEARCH}

In the course of this study, uncertainties or deficiencies in the factual data now available have become evident. Even though the needs for additional facts have been called.out in passing, it is worthwhile to summarize them, as follows.

a. The influence on corrosion and deposition of the following parameters should be studied for specific isotopes. The values of these parameters should include the range of likely possibilities in the FFTF.

- Hot-leg temperature

- Cold-leg temperature

- Temperature gradient along the loop

- Reynolds number

- Oxygen level

These studies require a loop in which hot sodium circulates. The corrosion and deposition of chromium, nickel, and iron can be studied in a nonradioactive loop.

b. Similar loop studies should be made using radioactive components, particularly cobalt-60.

c. The transport of nickel and cobalt should be compared.

d. Possibilities of erosion and spalling of thick deposits should be determined. 


\section{REFERENCES}

1. A. W. Thorley and C. Tyzack, The Corrosion Behavior of Steels and Nickel Alloys in High Temperature Sodium, IAEA Symposium on Alkali Metal Coolants, Vienna, Austria, November-December, 1966.

2. P. Roy and M. F. Gebhardt, Corrosion and Mass Transport of Stain/ess Stee/s in Sodium Systems, GEAP-13548, September 1969.

3. G. P. Wozadlo and C. N. Spalaris, Corrosion of Stainless Stee/ and Deposition of Particulates in Flowing Sodium Systems, GEAP-13544, September 1969.

4. Sodium Technology Development Program, Mass Transfer Investigations in Liquid Metal Systems, Quarterly Progress Report No. 6, December 1970-February 1971, GEAP.5693.

5. D. W. Shannon, Fast Reactor Corrosion and Chemistry, Interim Technical Progress Report No. 1, BNWL-483, 1967.

6. W. F. Brehm, Radioactive Mass Transport in FFTF Primary Piping, BNWL-808, 1968.

7. R. W. Lockhart, Sodium Mass Transfer - II. Screening Test Data and Analysis, Vol. 1, Mass Transfer Results, GEAP.3726, 1962.

8. F. G. Haag, "Material Transport in Sodium Systems," Chemical Engineering Progress Symposium Series $20,1957$.

9. Fission Product Contamination, January-March, 1970 Quarterly Report, Atomics International, Al-AEC-12948.

10. C. D. Flowers and L. A. Gerhardstein, Analogo-Hybrid Dynamic Simulation of the FFTF Reactor Heat Transport System, BNWL-707. April 1968.

11. C. P. Cobell, Fast Flux Test Facility Monthly Technical Progress Summary Report, WHAN-IR-27, August 1970.

12. W. C. Walker, FFTF Reference Concept Summary Description, BNWL, January 1969.

13. W. P. Kunkel, et al., LMFBR Fission Product Contamination and Control Studies-A Status Report, AI-AEC-21687, June 30, 1968.

14. From Table 1 of E. T. Boulette's (WADCO) Internal Letter of October 8, 1970 to W. F. Brehm.

15. C. A. Mansius (BNWL), Internal Letter of June 25, 1969 to W. L. Bunch.

16. Communication, T. Kabele (WADCO) to G. D. Collins (GE-BRD), August 17, 1971. 


\section{APPENDIX A. CALCULATION OF FFTF FUEL PIN CORROSION RATES}

The fuel pin corrosion rate shown in Table 4-4 was estimated by averaging the hot-and cold-channel corrosion rates over the length of the fuel pins. It was assumed for the FFTF that $50 \%$ of the channels would be hot and $50 \%$ cold, and that the respective peak temperatures would be 1100 and $1000^{\circ} \mathrm{F}$. A temperature profile for the fuel pins was constructed (Figure A-1): then, a corrosion rate profile was constructed (Figure A-1) with the aid of Figure 3-1.

The next step was to average arithmetically the area under the corrosion rate curves for $50 \%$ hot and $50 \%$ cold channels. The result was an average fuel pin corrosion rate of $0.156 \mathrm{mil} / \mathrm{year}$, which is the rate at an equivalent isothermal temperature of $\sim 1000^{\circ} \mathrm{F}$. The foregoing corrosion rate was used in Table 4-4.

Temperature and corrosion rate profiles were also constructed in Figure A-1 for the radial reflector. The sodium exits the radial reflector with the mixed mean temperature of $1050^{\circ} \mathrm{F}$. The addition of the radial reflector was necessary in order to calculate the respective corrosion rate fractions for the core, axial reflector, fission gas plenum, and radial reflector in subsection $\mathbf{4 . 4}$.

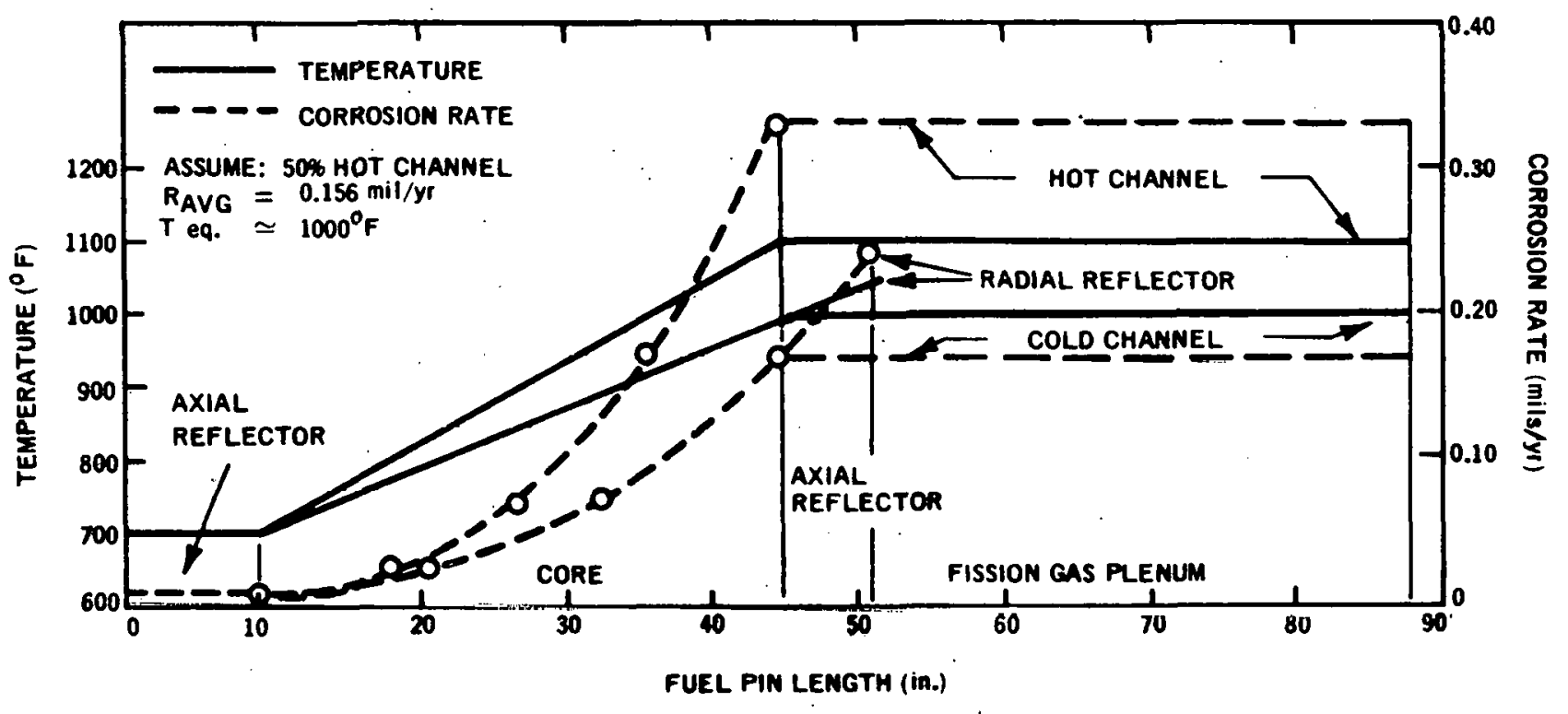

Figure A-1. Graphical Calculation of Average Fuel Pin Corrosion Rate 


\section{APPENDIX B. SUMMARY OF MEETING WITH WADCO}

WADCO and GE met on December 10, 1970 to discuss and compare calculations of analytical models for radionuclide transport in sodium systems, and to identify needed experimental data. *

a. GE and WADCO agreed on an analytical model for calculating dose rates and agreed on the following interim set of references for the required input data.

- GE has transmitted to WADCO:

- Equation and calculational model for calculating concentration of nuclides in each of four regions: (1) core, (2) axial reflector, (3) gas plenum, and (4) radial reflectors, using FFTF temperatures, velocity profiles, geometry, and oxygen levels of 3 to $5 \mathrm{ppm}$.

- WADCO has provided the following:

- Table of flux and energy for each of the foregoing four regions,

- ISOSHLD correction values to convert curies deposited to $\mathrm{R} / \mathrm{h}$, based on FFTF geometrical factors.

- Velocity data through IHX.

- Other reference interim assumptions agreed upon include:

- A working assumption on deposition pattern is equal deposition per unit of area (until such time as a more definitive pattern based on experimental data can be obtained; this recognizes that most of the primary loop is in one cell).

- Stainless steel is assumed to contain $0.1 \%$ maximum cobalt impurity in the FTR core.

- Nuclides are released at a rate proportional to their inventory in the steel (e.g., no selective leaching).

b. WADCO reviewed their data on radioisotope deposition patterns and provided these data.

c. GE used the FFTF engineering parameters transmitted in Reference 2. WADCO will assume responsibility for providing updated revisions.

d. The major uncertainties to be investigated were identified as the ones which most strongly affect the dose rates calculated:

- The distribution fraction of cobalt that deposits within the biological shield, especially the fuel gas plenum versus the fraction that deposits anywhere in the heat transport cell components.

- The degree to which selective leaching occurs, and its time dependency, especially cobalt and manganese.

*1. Letter, dated November 6, 1970, W. R. Wykoff (WADCO) to E. L. Zebroski (GE).

2. Letter, dated November 16, 1970, W. R. Wykoff (WADCO) to E. L. Zebroski (GE).

3. Letter, dated December 4, 1970, G. D. Collins (GE) to W. R. Wykoff (WADCO). 


\section{DISTRIBUTION}

Director, Div. of Reactor Dev. \& Tech. Division of Reactor Development \& Technology United States Atomic Energy Commission Washington, D. C. 20545

Asst. Director for Project Management Division of Reactor Development \& Technology United States Atomic Energy Commission Washington, D. C. 20545

Asst. Director for Plant Engineering

Division of Reactor Development \& Technology United States Atomic Energy Commission

Washington, D. C. 20545

Asst. Director for Reactor Engineering Division of Reactor Development \& Technology United States Atomic Energy Commission Washington, D. C. 20545

Asst. Director for Reactor Technology Division of Reactor Development \& Technology United States Atomic Energy Commission Washington, D. C. 20545

Asst. Director for Program Analysis Division of Reactor Development \& Technology United States Atomic Energy Commission Washington, D. C. 20545

Chief, Coolant Chemistry Branch

Division of Reactor Development \& Technology United States Atomic Energy Commission Washington, D. C. 20545

Chief, Fuels \& Materials Branch .

Division of Reactor Development \& Technology United States Atomic Energy Commission Washington, D. C. 20545

RDT Site Office

United States Atomic Energy Commission General Electric Company 310 De Guigne Drive Sunnyvale, California 94086
Chief, Reactor Vessels Branch Division of Reactor Development \& Technology United States Atomic Energy Commission Washington. D. C. 20545

Chief, Liquid Metal Projects Branch

Division of Reactor Development \& Technology United States Atomic Energy Commission Washington. D. C. 20545

Chief, Fuel Engineering Branch

Division of Reactor Development \& Technology United States Atomic Energy Commission Washington, D. C. 20545

1 LMFBR Program Manager Division of Reactor Development \& Technology United States Atomic Energy Commission Washington, D. C. 20545

1 Director, LMFBR Program Office Argonne National Laboratory 9700 South Cass Avenue Argonne, Illinois 60439

Director, Contracts Division

United States Atomic Energy Commission San Francisco Operations Office 2111 Bancr oft Way Berkeley, California 94704

Chief, California Patent Group United States Atomic Energy Commission San Francisco Operations Office P. O. Box 808 Livermore, California 94550

United States Atomic Energy Commission Division of Technical Information Extension P. O. Box 62

Oak Ridge, Tennessee 37830

Attention: T. W. Laughlin

Director, Div. of Reac.tor Licensing

Division of Reactor Licensing United States Atomic Energy Commission Washington, D. C. 20545

Director, Div. of Reactor Standards Division of Reactor Standards United States Atomic Energy Commission Washington, D. C. 20545 


\section{BREEDER REACTOR DEPARTMENT}

SUNNYVALE, CALIFORNIA 94086

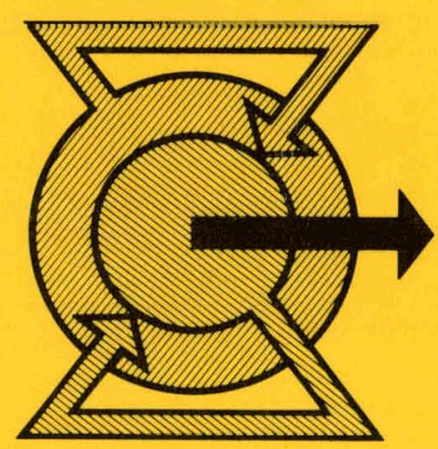

Expanding the World's Energy Reserves

GENERAL ELECTRIC 